\title{
Soil amplification with a strong impedance contrast: Boston, Massachusetts
}

Laurie G. Baise $^{\mathrm{a},}$, , James Kaklamanos ${ }^{\mathrm{b}}$, Bradford M. Berry ${ }^{\mathrm{c}}$, Eric M. Thompson ${ }^{\mathrm{d}}$

a 113 Anderson Hall, Tufts University, Medford, MA 02155

* Corresponding author.

E-mail address: laurie.baise@tufts.edu

Telephone: 617.627.2211

b 315 Turnpike Street, Merrimack College, North Andover, MA 01845

${ }^{c} 113$ Anderson Hall, Tufts University, Medford, MA 02155

d 1711 Illinois St. U.S. Geological Survey, Golden, CO 80401

Keywords: impedance contrast, site response, site amplification, velocity model, bedrock model, Boston

Abstract: In this study, we evaluate the effect of strong sediment/bedrock impedance contrasts on soil amplification in Boston, Massachusetts, for typical sites along the Charles and Mystic Rivers. These sites can be characterized by artificial fill overlying marine sediments overlying glacial till and bedrock, where the depth to bedrock ranges from 20 to $80 \mathrm{~m}$. The marine sediments generally consist of organic silts, sand, and Boston Blue Clay. We chose these sites because they represent typical foundation conditions in the city of Boston, and the soil conditions are similar to other high impedance contrast environments. The sediment/bedrock interface in this region results in an impedance ratio on the order of ten, which in turn results in a significant amplification of the ground motion. Using stratigraphic information derived from numerous boreholes across the region paired with geologic and geomorphologic constraints, we develop a depth-to-bedrock model for the greater Boston region. Using shear-wave velocity profiles from 30 locations, we develop average velocity profiles for sites mapped as artificial fill, glaciofluvial deposits, and bedrock. By pairing the depth-to-bedrock model with the surficial geology and the average shear-wave velocity profiles, we can predict soil amplification in Boston. We compare linear and equivalent-linear site response predictions for a soil layer of varying thickness over bedrock, and assess the effects of varying the bedrock shear-wave velocity $\left(\mathrm{V}_{\mathrm{Sb}}\right)$ and quality factor (Q). In a moderate seismicity region like Boston, many earthquakes will result in ground motions that can be modeled with linear site response methods. We also assess the effect of bedrock depth on soil amplification for a generic soil profile in artificial fill, using both linear and equivalent-linear site response models. Finally, we assess the accuracy of the model results by comparing the predicted (linear site response) and observed site response at the Northeastern University (NEU) vertical seismometer array during the 2011 M 5.8 Mineral, Virginia, earthquake. Site response at the NEU vertical array results in amplification on the order of 10 times at a period between $0.7-0.8 \mathrm{~s}$. The results from this study provide evidence that the mean short-period and mean intermediate-period amplification used in design codes (i.e., from the $\mathrm{F}_{\mathrm{a}}$ and $F_{v}$ site coefficients) may underpredict soil amplification in strong impedance contrast environments such as Boston. 


\section{Introduction}

Recent earthquakes such as the 2011 M 5.8 Mineral, Virginia, earthquake have focused attention on seismic hazards and risk in the Central and Eastern United States (CEUS), especially in regions with moderate seismic activity and high population density (e.g., Hough, 2012). In the CEUS, where bedrock is harder and less fractured than in the Western U.S., strong bedrock/soil seismic impedance contrasts are common, and the resulting soil amplification can play a major role in damage patterns over large areas even due to a moderate sized event. When evaluating seismic hazard in regions such as Boston, Massachusetts, where artificial fill and marine soils are underlain by hard, competent bedrock-resulting in a strong impedance contrast-particular attention should be paid to site effects, and the influence of the impedance contrast on ground motions.

Strong impedance contrasts have played a role in soil amplification for other regions in the CEUS as well as in other tectonically active regions. Banab et al. (2012) analyzed soil amplification in Ottawa, Canada. The geology of Ottawa consists primarily of soft clay sediments with low shear-wave velocity $\left(\mathrm{V}_{\mathrm{S}} \sim 150 \mathrm{~m} / \mathrm{s}\right)$, underlain by hard bedrock with high shear-wave velocity $\left(\mathrm{V}_{\mathrm{S}} \sim 2700 \mathrm{~m} / \mathrm{s}\right)$, resulting in an impedance ratio of at least 18 . The impedance ratio is calculated as $\rho_{2} V_{S 2} /\left(\rho_{1} V_{S 1}\right)$, where $\rho_{1}$ and $\rho_{2}$ are the densities of the upper and lower layer, respectively, and $V_{S 1}$ and $V_{S 2}$ are the corresponding shear-wave velocities. Other examples of soil amplification at soft clay sites with a strong impedance contrast at the bedrock interface include the 1985 M 8.1 Mexico City earthquake (Seed et al., 1988; Kramer, 1996) and the 2001 M 6.8 Nisqually earthquake (Molnar et al., 2004). The damage in Mexico City was attributed in part to the strong impedance contrast between the lake deposits $\left(\mathrm{V}_{\mathrm{S}} \sim 75 \mathrm{~m} / \mathrm{s}\right)$ and the underlying cemented sand and gravel $\left(\mathrm{V}_{\mathrm{S}} \sim 500-900 \mathrm{~m} / \mathrm{s}\right)$, resulting in amplification ratios near 10 at periods of approximately 2 seconds (Kramer, 1996). The 2001 Nisqually earthquake caused noticeable soil amplification in Victoria, British Columbia, which has similar geology to the Boston area: bedrock overlain by glacial deposits, marine clay, and organic material. The clay consists of an overconsolidated layer ("brown Victoria clay") on top of a normally consolidated layer ("grey Victoria clay"), not unlike typical sites in Boston underlain by the Boston Blue Clay. Shear-wave velocity measurements in the brown Victoria clay ( 164-262 
$77 \mathrm{~m} / \mathrm{s})$ are low compared to bedrock ( 2000-3500 m/s), and bedrock depth ranges from 0-30 m. In

78 Victoria, observed peak accelerations at soil sites were up to six times that of observed peak accelerations at bedrock sites at periods between $0.2-0.5$ seconds.

In this paper, we explore the effect of the observed strong impedance contrasts for soil profiles in Boston, where the stratigraphy includes artificial fill over marine clay $\left(\mathrm{V}_{\mathrm{S}} \sim 200-400\right.$

\section{Data Resources}

\subsection{Geology}

The City of Boston is located in a shallow sedimentary basin within the fault-bounded Boston Basin, which is defined by north-dipping faults that separate granitic and volcanic rocks from meta-sedimentary rocks (Cambridge Argillite and Roxbury Conglomerate). The shape of bedrock in the basin is the result of preferential erosion of weaker rock during repeated glaciation throughout the Pleistocene (Barosh and Woodhouse, 2011/2012). The location and geometry of present river channels as well as previous paleochannels are largely a function of the 
bedrock shape (FitzGerald et al., 2005). Boston soil conditions can be summarized generally in the following manner (Woodhouse and Barosh, 2011/2012):

1. Boston has been extensively filled, resulting in a layer of miscellaneous, often nonengineered fill overlying organic materials. The artificial fill is usually underlain by the marine clay unit (called the Boston Blue Clay), and is often coincident with the deepest soil sites in the region.

2. Boston Harbor includes the mouths of two major rivers: the Charles and Mystic Rivers. Both these river channels are underlain by marine clay.

3. Boston was heavily glaciated and is surrounded by glacial drumlins. In general, bedrock is overlain by glacial till in the region, and both materials exhibit high shear-wave velocities.

A surficial geology map for greater Boston is shown in Figure 1. Note that glacial till and bedrock are simplified to a single unit in this map and also include glacial ground and end moraines. The glaciofluvial deposits include glacial outwash plains, eskers, kames, and kame fields (Brankman and Baise, 2008).

\subsection{Geotechnical Data}

The map in Figure 1 includes borehole locations where soil stratigraphy is known, as well as locations where spectral analysis of surface waves (SASW) and seismic cone penetration testing ( $\mathrm{SCPT}$ ) velocity measurements are available. The 500+ boreholes shown in Figure 1 include stratigraphic layer boundaries and were collected from numerous projects in the region (Boston Society of Civil Engineers logs; Central Artery/Tunnel (CA/T) Project; Massachusetts Water Resources Authority) (BSCE, 1961; Haley \& Aldrich, 1991). SASW velocity profiles were available at 27 locations (Thompson et al., 2014) and the sCPT were available at 3 locations (Santagata and Kang, 2007).

We grouped the 30 shear-wave velocity $\left(\mathrm{V}_{\mathrm{S}}\right)$ profiles by surficial geology unit: artificial fill, glaciofluvial deposits, and bedrock, as summarized in Figure 2. Drumlins, glacial till, and bedrock were grouped together as one unit because the velocity profiles were consistent and the sediments are generally shallow (bedrock). The $\mathrm{V}_{\mathrm{S}}$ profiles in the artificial fill indicate a gradient of low $\mathrm{V}_{\mathrm{S}}(\sim 200-400 \mathrm{~m} / \mathrm{s})$ down to $30-50 \mathrm{~m}$ depth. The $\mathrm{V}_{\mathrm{S}}$ profile in the glaciofluvial deposit also indicates low $\mathrm{V}_{\mathrm{S}}$ in the shallow sediments $(<10 \mathrm{~m})$; however, the available boreholes with stratigraphic information indicate that the glaciofluvial unit is relatively shallow and underlain by 
bedrock. The $\mathrm{V}_{\mathrm{S}}$ profiles in glacial till and bedrock indicate that the near-surface bedrock sites have a thin soil cover or weathered layer but reach $V_{S}$ typical for bedrock (>2000 m/s) at depths between 1 and $10 \mathrm{~m}$.

To characterize the stratigraphy in Boston, we used information from the borehole logs, $\mathrm{V}_{\mathrm{S}}$ profiles, and the literature. The generalized soil properties are provided in Table 1 . The height of the soil column $(\mathrm{H})$ varied between 10 and 80 meters. The shear-wave velocity of the soil $\left(\mathrm{V}_{\mathrm{Ss}}\right)$ measurement ranged from 100 to $500 \mathrm{~m} / \mathrm{s}$, and the shear-wave velocity of the bedrock $\left(\mathrm{V}_{\mathrm{Sb}}\right)$ measurement ranged from $1750 \mathrm{~m} / \mathrm{s}$ to $2250 \mathrm{~m} / \mathrm{s}$. The density of the soil $\left(\rho_{\mathrm{s}}\right)$ was calculated as a function of $\mathrm{V}_{\mathrm{S}}$, following Brocher (2005). Hashash et al. (2014) defined a reference rock unit weight for Eastern North America (ENA) of $27 \mathrm{kN} / \mathrm{m}^{3}$, corresponding to a density of 2.75 $\mathrm{g} / \mathrm{cm}^{3}$, which we used as the density of the bedrock $\left(\rho_{\mathrm{b}}\right)$. For linear site response, we assumed a soil quality factor $(\mathrm{Q})$ range of 10 to 30 , which is equivalent to a damping ratio $(\xi)$ range of $1.67 \%$ to $5 \%(\xi=1 /(2 \mathrm{Q}))$.

\subsection{Ground Motion Data}

Using recorded ground motions from the 2011 M 5.8 Mineral, Virginia, earthquake, we validate site response models at a vertical seismometer array in Boston. The Northeastern University (NEU) site is located in the Charles River basin and represents a typical artificial fill site with a thick layer of marine clay (Johnson, 1989). The NEU vertical seismometer array recorded on both a surface accelerometer at $0 \mathrm{~m}$ depth (NEU00) and a downhole accelerometer at $51 \mathrm{~m}$ depth (NEU51). The epicentral distance for the 2011 Mineral earthquake is $760 \mathrm{~km}$ and the recorded peak ground acceleration (PGA) at the site is $0.004 \mathrm{~g}$ (NEU00), which is within the linear range of soil behavior. The stratigraphy at NEU is $2.5 \mathrm{~m}$ of fill, $2.5 \mathrm{~m}$ of sand, $43 \mathrm{~m}$ of clay, and $2 \mathrm{~m}$ of till (Yegian, 2014). The downhole recorded ground motions at NEU51 are compared with those recorded at the Jamaica Pond (JP) bedrock site ( $2 \mathrm{~km}$ away), which is assumed to behave as a bedrock outcrop site.

\section{Results and Discussion}

This study was subdivided into three phases. The first phase involved the development of average soil profile models for sites based on surficial geology, mean stratigraphy, and mean $\mathrm{V}_{\mathrm{S}}$, as well as developing a depth-to-bedrock model for the greater Boston region. The second phase 
was to assess the influence of the strong impedance contrast on predicted soil amplification using linear and equivalent-linear site response models in Boston. This involved developing a suite of design ground motions for Boston and analyzing the effects of changes in the soil profile on soil amplification. The third phase of the work was to validate the soil amplification models in Boston using the recorded ground motions from the NEU array for the 2011 Mineral earthquake.

\subsection{Regional Soil and Bedrock Models}

\subsubsection{Stratigraphic and $V_{S}$ Model}

In order to parametrically study the effect of the strong impedance contrast on soil amplification in greater Boston and to predict regional site effects, we developed a generic $\mathrm{V}_{\mathrm{S}}$ profile for sediment sites. Based on a comparison of the mean $V_{S}$ profiles for artificial fill, glaciofluvial deposits, and bedrock shown in Figure 2, the shear-wave velocity in the upper 5 meters is similar $(\sim 200 \mathrm{~m} / \mathrm{s})$. The primary differences in the $\mathrm{V}_{\mathrm{S}}$ profiles relate to the depth of the sediment/bedrock interface. In order to assess site response at a given location where the depth to bedrock $(\mathrm{H})$ is known or estimated, the $\mathrm{V}_{\mathrm{S}}$ profile can be truncated appropriately at depth $\mathrm{H}$ (for Boston, between $10-80 \mathrm{~m})$. As a result, we have a single $V_{S}$ profile that can be paired with the depth-to-bedrock model across the Boston region. The mean $\mathrm{V}_{\mathrm{S}}$ profile was then linked to the mean stratigraphy found by averaging the thickness for a given soil type from the soil boreholes, as shown in Figure 3. The available $\mathrm{V}_{\mathrm{S}}$ profiles typically ended at depths between 30 and $50 \mathrm{~m}$; however, we extended the $\mathrm{V}_{\mathrm{S}}$ profile with a gradient to $80 \mathrm{~m}$ to include the greater bedrock depths observed in borehole logs in the region. The gradient was developed by extending the mean gradient observed in the upper $50 \mathrm{~m}$ of the soil profile.

\subsubsection{Depth-to-Bedrock Model}

A bedrock model was developed so that a best-estimate depth to bedrock could be assigned at any location in the project area without a site-specific stratigraphic profile. The depth-to-bedrock model draws from stratigraphic information from over 500 boreholes paired with geologic and geomorphologic information for the region. Figure 4 shows the depth to bedrock as measured in geotechnical boreholes. First, we use the surficial geology to define a rock/sediment boundary, which is best seen in Figure 4 as the dark shade of brown. Using this rock/sediment boundary to define the edge of the sedimentary basin and assuming that sediment thickness is zero at this boundary and increases away from this boundary, we define a general 
"trend" of the basin as a function of distance to bedrock $\left(\mathrm{R}_{\mathrm{b}}\right)$ and distance to coast $\left(\mathrm{R}_{\mathrm{c}}\right)$. This shape function (SF) is defined so that its value is one at the coast and zero at the sedimentbedrock interface: $S F=R_{c} /\left(R_{c}+R_{b}\right)$. We then calibrate the $S F$ to the measured bedrock depths, where the square of SF is related to the square root of the bedrock depth. Applying the "kriging-with-a-trend" interpolation method, we use the SF surface as a trend with the bedrock depth residuals from the SF trend model. The semivariogram for this model indicates strong spatial correlation of the bedrock residuals to the SF trend model.

The resulting bedrock depth model is shown in Figure 5. The bedrock depth model is a trend model and does not accurately capture the shallowest or deepest bedrock depths. For example, at the NEU station the model predicts a depth to bedrock of $30 \mathrm{~m}$, as compared to a borehole observation of $50 \mathrm{~m}$. Other borehole observations near NEU, however, range from 20 to $50 \mathrm{~m}$, indicating a large amount of variability over a relatively short distance that is difficult to capture in the depth-to-bedrock model.

\subsection{Evaluating Soil Amplification}

In the second phase of the work, we evaluated ground-motion amplification for typical soil conditions in Boston (as described in Section 3.1). Soil amplification was estimated with linear and equivalent-linear site response analyses.

\subsubsection{Parametric Study for Linear Soil Amplification}

Linear site response is the simplest of the analysis methods, and the predicted amplification spectra are not sensitive to the level of shaking or the input ground motion. Because probabilistic estimates of ground shaking in Boston are low (PGA $=0.08 g$ for $2 \%$ probability of exceedance in 50 years on NEHRP site class A; Petersen et al., 2008), there are many earthquake scenarios where linear amplifications would remain applicable. Kaklamanos et al. $(2013$, 2015) found that linear site response models were sufficient at short spectral periods when PGA $<0.1 \mathrm{~g}$. We computed the linear amplifications with the program NRATTLE (written by C. Mueller with modification by R. Herrmann and distributed with the Boore [2005] program SMSIM). For our parametric study, we assumed a homogeneous soil layer of shear-wave velocity ( $\mathrm{V}_{\mathrm{Ss}}$ ranging from 100 to $500 \mathrm{~m} / \mathrm{s}$ ) and thickness (H ranging from 10 to $80 \mathrm{~m}$ ) overlying bedrock. In addition to varying $\mathrm{V}_{\mathrm{Ss}}$ and $\mathrm{H}$, we tested two values of the bedrock shear wave velocity $\left(\mathrm{V}_{\mathrm{Sb}}\right): 2000 \mathrm{~m} / \mathrm{s}$ (from this study) and $3000 \mathrm{~m} / \mathrm{s}$ (corresponding to the reference rock for 
CEUS recommended by Hashash et al., 2014), both corresponding to NEHRP Site Class A. We also tested two values for the soil quality factor (Q): 15 and 30. In order to evaluate the results in the context of soil amplification in terms of design codes (i.e., $F_{a}$ and $F_{v}$ ), we calculated the mean amplitude of the soil transfer function over the short period (0.1-0.5 s) and the intermediate period (0.5-1.5 s) ranges. We also calculated the period at which the maximum amplitude occurred (fundamental period) for each soil transfer function in order to understand the resonance effects.

Figures 6 and 7 display contour plots of the mean short-period (panels (a)-(b)) and intermediate-period (panels (d)-(e)) amplitudes as a function of $\mathrm{V}_{\mathrm{Ss}}$ on the horizontal axis versus $\mathrm{H}$ on the vertical axis. Figure 6 displays the results for $\mathrm{V}_{\mathrm{Sb}}=2000 \mathrm{~m} / \mathrm{s}$, and Figure 7 displays the results for $\mathrm{V}_{\mathrm{Sb}}=3000 \mathrm{~m} / \mathrm{s}$. As observed in the plots, the highest mean short-period amplification occurs for low $\mathrm{V}_{\mathrm{Ss}}(<200 \mathrm{~m} / \mathrm{s})$ and shallow soil $(\mathrm{H}<20 \mathrm{~m})$, whereas the effect on the mean intermediate-period amplification is more pronounced for $\mathrm{H}$ between 20 and $50 \mathrm{~m}$ and low $\mathrm{V}_{\mathrm{Ss}}$ $(<200 \mathrm{~m} / \mathrm{s})$. Figure 8 displays a contour plot of the fundamental period from the soil transfer function. Because the fundamental period does not vary with $\mathrm{Q}$ or $\mathrm{V}_{\mathrm{Sb}}$, only one panel (Figure 8(a)) is shown for the linear model. As expected, the fundamental period increases as thickness of the soil column increases and as the shear-wave velocity of the soil decreases. The equivalent-linear results in Figures 6-8 will be discussed in Section 3.2.3.

\subsubsection{Suite of Design Ground Motions}

Because equivalent-linear site response (section 3.2.3) is sensitive to the level of shaking and the input ground motion, we developed a suite of design ground motions for the region. The suite of design ground motions was derived from earthquakes occurring in the CEUS and Central and Eastern Canada. The design ground motion suite used herein is an update over prior published design ground motion sets for Boston (Hines et al., 2011; Somerville and Collins, 2003). Using the database of earthquake events created for the Next Generation Attenuation-East (NGA-East) project (Goulet et al., 2014), we filtered the database to develop a list of recordings that would be appropriate for Boston. The filtering criteria for the database were determined from a seismic hazard deaggregation plot for peak ground acceleration with $2 \%$ probability exceedance in 50 years, shown in Figure 9. The deaggregation plot was made using the U.S. Geological Survey National Seismic Hazard Mapping Project website (Petersen et al., 2008) with geographic coordinates for a point in Boston $\left(42.358^{\circ} \mathrm{N},-71.060^{\circ} \mathrm{W}\right)$. From the deaggregation 
plot, we observe that the hazard is controlled by background seismicity with distances from 0 to $150 \mathrm{~km}$ and magnitudes from 4.5 to 6 . The probabilistic PGA for NEHRP Class A (hard rock) sites in Boston is $0.081 \mathrm{~g}$. To determine a set of appropriate records, the NGA-East database was filtered for PGA between $0.01 g$ and $0.2 g$, magnitude between 4.5 and 6 , and distance less than $150 \mathrm{~km}$, which resulted in a list of five different earthquake events and 43 recordings that were appropriate for design ground motions in Boston, as detailed in Table 2.

To develop a suite of 8 recordings from our list of 43 candidate motions, we used the program SigmaSpectra, which selects ground motions by scaling them to a target design spectrum and standard deviation (Kottke and Rathje, 2013). The target response spectrum was based upon the ASCE 7 Site Class A provisions for bedrock (ASCE, 2013), which can be seen as the black line in Figure 10. We set the fitting window from 0.01 to $2 \mathrm{sec}$ with 750 logarithmically spaced points. The density of points is increased twofold (in logarithmic space) in the range $0.3 \leq \mathrm{T} \leq 1 \mathrm{~s}$, because this range is particularly important for site response in Boston (the fundamental periods tend to fall in this range based on the $\mathrm{V}_{\mathrm{S}}$ profile and the typical depth to bedrock). With these inputs, the program chose a suite of 8 ground motion records that when scaled had the lowest median root mean square error (RMSE). We used only one horizontal component per recording station (choosing the one with the lowest RMSE), and constrained the scaling factors between 0.25 and 4 . Our final suite of design ground motions is presented in Table 3 and is plotted as the colored lines in Figure 10. The median of these eight motions can be seen as the thick blue line in Figure 10. Because of the weighting chosen, the motions most closely match the design spectrum in the range of $0.3 \leq \mathrm{T} \leq 1 \mathrm{~s}$. The largest spectral acceleration of the median curve is $0.22 g$ at $\mathrm{T}=0.12 \mathrm{~s}$, which can be observed as a peak in the individual response spectra. The lack of energy in the response spectra above $2 \mathrm{sec}$ is a result of the use of small-magnitude earthquakes in the design ground motions. Larger, more distant earthquakes would be needed to adequately sample the longer period range.

\subsubsection{Parametric Study for Equivalent Linear Soil Amplification}

Equivalent-linear site response analyses incorporate nonlinear soil behavior through the use of strain-dependent modulus-reduction and damping curves; the program SHAKE2000 was used for the equivalent-linear calculations in this study (Schnabel et al., 1972; Idriss and Sun, 1991; Ordóñez, 2014). In order to perform site response calculations using SHAKE, we needed to further define the soil properties, including unit weights, modulus-reduction models, and 
damping ratio models, as shown in Table 4. Unit weights were assigned from values in literature (Lambe and Whitman, 1969). The Seed and Idriss (1970) modulus-reduction and damping curves for sand were used for the fill layer and the sand and gravel layer. The Vucetic and Dobry (1991) modulus-reduction and damping curves for clay with plasticity index (PI) of 30 were used for the organic deposits (Dobry et al., 1996; Kishida et al., 2009) and the Boston Blue Clay (Lambe and Whitman, 1969). There are additional modulus reduction curves that take into account confining pressure (e.g., Zhang et al., 2005; Darendeli, 2001), which has been shown to be an important factor. The effect of using these modulus reduction curves in Boston may be evaluated in future work.

For the equivalent linear soil amplification parametric study, we first assumed a constant soil layer over bedrock, and varied $\mathrm{V}_{\mathrm{Ss}}$ and $\mathrm{H}$ over the ranges that were also consistent with the linear soil amplification parametric study, shown in Table 1. We used the design ground motions specified in Table 3 and Figure 10 and present the results in terms of (i) the mean short-period amplification, (ii) mean intermediate-period amplification, and (iii) fundamental period of the median site-response transfer function. Equivalent linear results of (i) for $\mathrm{V}_{\mathrm{Sb}}=2000 \mathrm{~m} / \mathrm{s}$ and $\mathrm{V}_{\mathrm{Sb}}=3000 \mathrm{~m} / \mathrm{s}$ are shown in Figures 6(c) and 7(c) respectively; comparable results of (ii) at $V_{S b}=2000 \mathrm{~m} / \mathrm{s}$ and $V_{S b}=3000 \mathrm{~m} / \mathrm{s}$ are shown in Figures 6(f) and 7(f), respectively; and the associated fundamental period function of (iii) is shown in Figure 8(b). The selection of Q is not relevant for equivalent-linear analyses because damping is specified through a damping curve, instead of by a strain-constant parameter. The equivalent-linear results show peak mean shortperiod amplification for soil column heights near $50 \mathrm{~m}$ and soil shear-wave velocity near 500 $\mathrm{m} / \mathrm{s}$, and peak mean intermediate-period amplification for soil column heights near $80 \mathrm{~m}$ and soil shear wave velocity near $300 \mathrm{~m} / \mathrm{s}$. Compared to the linear results, the equivalent-linear results show slightly less amplification for low shear-wave velocities $\left(\mathrm{V}_{\mathrm{S}}<200 \mathrm{~m} / \mathrm{s}\right)$, where nonlinear soil behavior will be strongest. When comparing the fundamental periods of the linear and equivalent-linear analyses in Figure 8 , it is obvious that the fundamental period of the equivalent-linear transfer function is slightly larger. Because the equivalent-linear analyses reduce the shear modulus of the soil, an increase in the fundamental period is expected. For thicker deposits (large H) and higher Vs, the equivalent linear results show more amplification most likely related to the increased effect of the impedance contrast due to a reduction in shear modulus. 


\subsubsection{Linear and Equivalent-Linear Comparisons for Generic $V_{S}$ Profile}

Next we assessed soil amplification using the generic $V_{S}$ profile for artificial fill (Figure 3 ), and varying the bedrock depth $\mathrm{H}$ from $10 \mathrm{~m}$ to $80 \mathrm{~m}$. Figure 11 compares the results from the linear and equivalent-linear methods in terms of mean short-period amplification (Figure 11(a)), mean intermediate period amplification (Figure 11(b)), and fundamental period (Figure 11(c)) with varying height of the soil column. Figure 11 also shows the mean amplification in terms of site coefficients $F_{a}$ (short period) and $F_{v}$ (intermediate period) assuming the design groundmotion levels and site classes. Because the design ground motions have been selected for Site Class A, and the profiles are Site Class C-D, the tabulated values of $F_{a}$ and $F_{v}$ from the design code are divided by 0.8 (the site coefficient for Site Class A). Notice that the $F_{a}$ and $F_{v}$ values change at $\mathrm{H}=15 \mathrm{~m}$ because the site class shifts from Site Class $\mathrm{C}$ to Site Class D at this $\mathrm{H}$. The peak mean short period amplification is for $\mathrm{H}=20 \mathrm{~m}$ and the peak intermediate period amplification is for the maximum $\mathrm{H}$ of $80 \mathrm{~m}$. From Figure 11, the mean short-period amplification is consistently higher than the $\mathrm{F}_{\mathrm{a}}$ design values (although they are similar in the 30$40 \mathrm{~m}$ range) and the mean intermediate-period mean amplification is higher than the $F_{v}$ design values when the soil column is greater than $45 \mathrm{~m}$ thick. A comparison with observed amplifications at the NEU and JP sites will be discussed in section 3.3.

To better understand the soil amplification for the generic $V_{S}$ profile, we plot the surface/input amplification ratios in Figure 12 for soil column heights of $10 \mathrm{~m}, 30 \mathrm{~m}, 50 \mathrm{~m}$, and $80 \mathrm{~m}$. The plots show the influence of $\mathrm{Q}$ and $\mathrm{V}_{\mathrm{sb}}$ on the amplifications of the linear site response model (larger $\mathrm{Q}$ and $\mathrm{V}_{\mathrm{sb}}$ result in larger amplifications), but these results do not influence the fundamental period of the transfer function. Compared to the linear transfer functions, the peaks of the equivalent-linear transfer functions are shifted slightly to longer period as would be expected. The equivalent-linear model provides less amplification than the linear model at shorter periods (where nonlinear effects are most pronounced), but generally greater amplification at longer periods (particularly for deeper sites). The transfer functions for four specific profiles in Figure 12 mirror the general trends observed in Figure 11.

To further understand the soil behavior in the equivalent linear calculations, in Figure 13 we show the maximum shear strain with depth (Figure 13(a)), maximum acceleration with depth (Figure 13(b)), shear modulus reduction with depth (Figure 13(c)), and damping ratio with depth (Figure 13(d)) for the equivalent-linear model for two soil column heights $(10 \mathrm{~m}$ and $80 \mathrm{~m})$. 
Nonlinear soil behavior is generally modest throughout most of the profile, except in the depth range of 5-15 $\mathrm{m}$ (which corresponds to the sand and gravel layer), where the shear modulus is more greatly reduced and the damping ratio is more greatly increased, relative to the surrounding soil layers. For shear strains exceeding $0.01 \%$ (as observed throughout most of the soil profiles), Kaklamanos et al. $(2013,2015)$ found that the equivalent-linear model resulted in a statistical improvement over the linear model at short spectral periods, although the shear strains in this study are relatively close to the linear / equivalent-linear threshold (i.e., the difference is not major).

\subsection{Validation for the 2011 Mineral Earthquake}

The 2011 M 5.8 Mineral, Virginia, earthquake allows us to validate the site response models for Boston because the earthquake was recorded at the NEU vertical array, which has similar stratigraphy to the artificial fill sites used in this study. Empirical transfer functions have been used at other vertical array sites to validate site response analysis at Lotung (Glaser and Baise, 2000), at Garner Valley (Bonilla et al., 2002), and at Treasure Island and Yerba Buena Island (Baise et al., 2003). While the NEU vertical array includes a downhole recording at depth, which we refer to as the bedrock motion, we also use the nearby recording on rock at Jamaica Pond as a reference outcrop motion. The Jamaica Pond station (JP) is $2.0 \mathrm{~km}$ southwest of NEU (see Figure 1). Figure 15 shows the smoothed Fourier amplitudes for the soil surface, rock outcrop, and bedrock motions at the NEU vertical array. Amplification by the soil (black line) relative to the bedrock (gray line) and outcrop (blue line) can be seen between 0.1 and 2 sec. The differences between the bedrock and the outcrop amplitudes are mostly explained by the downgoing-wave effect as the primary difference is a dip in the amplitude of the downhole record (NEU51) near 0.6 s (Thompson et al., 2009). From Figure 15, we can conclude that the bedrock ground motion felt at the NEU vertical array was similar to the outcrop ground motion felt at Jamaica Pond. The resulting surface/bedrock transfer functions are shown in Figure 15. For the surface/bedrock transfer function, the results show 15 times amplification at a fundamental period of 0.7 seconds, which is consistent with Figure 12(c) $(\mathrm{H}=50 \mathrm{~m})$. These results are consistent with those reported by Hayles et al. (2001), who measured H/V microtremor measurements and found fundamental periods between 0.63 and $1 \mathrm{~s}$ at deep soil 
sites in proximity to the NEU array. The Hayles et al. (2001) study also reported amplification ratios between 2 and 13 for the same sites.

Figure 15 compares the NEU surface/bedrock transfer function with the theoretical linear plane-wave transfer functions for vertically propagating SH-waves using the generic artificial fill $\mathrm{V}_{\mathrm{S}}$ profile truncated at a bedrock depth of $50 \mathrm{~m}$ (as observed in a borehole log at the NEU vertical array site). For this calculation, we also tested a $\mathrm{Q}$ of 15 and 30 and $\mathrm{V}_{\mathrm{Sb}}$ of $2000 \mathrm{~m} / \mathrm{s}$ and $3000 \mathrm{~m} / \mathrm{s}$; the optimal fit was for $\mathrm{Q}=30$ and $\mathrm{V}_{\mathrm{Sb}}=3000 \mathrm{~m} / \mathrm{s}$, which is shown in the figure. The lower Q (15) and lower $\mathrm{V}_{\mathrm{Sb}}(2000 \mathrm{~m} / \mathrm{s})$ values resulted in less amplification than observed (plots of these transfer functions were shown in Figure 12). Returning to Figure 11, we observe that the observed mean amplifications for the surface/downhole pair (NEU00/NEU51) and surface/outcrop pair (NEU00/JP) are underpredicted by all the site response models as well as the site coefficients. Plotting the results at the observed bedrock depth of $50 \mathrm{~m}$, the surface/downhole and surface/outcrop amplifications are similar to each other: the mean shortperiod amplifications are both near 3 (3.06 and 3.13, to be exact), and the mean intermediateperiod amplifications are both near 5 (5.29 and 5.07). Using the results from Figure 11 and $\mathrm{H}=$ $50 \mathrm{~m}$, the predicted mean short-period amplifications for this site range from 2 to 2.5 (depending on the model used), and the expected mean intermediate-period amplification for this site ranges between 3 and 4 . In summary, the site coefficients $\left(F_{a}\right.$ and $\left.F_{v}\right)$ significantly underpredict the observed amplifications.

\section{Summary and Conclusions}

In this study, we characterized soil amplification in Boston with a focus on typical soil profiles near the Charles and Mystic Rivers. We assessed the importance of the soil/bedrock impedance contrast, thickness of soil, and soil properties on characterizing the site response in terms of amplitude and frequency content and summarized our results in terms of mean amplification over the short period (0.1-0.5 s) and intermediate period (0.5-1.5 s) ranges. With our understanding of the geology in the region and using previously published geotechnical data, we developed a depth-to-bedrock model for the greater Boston region. Using $\mathrm{V}_{\mathrm{S}}$ profiles from 30 locations, we developed average velocity profiles for three geologic units found in the greater Boston region (artificial fill, glaciofluvial deposits, and glacial till / bedrock). By pairing the depth-to-bedrock model with the average velocity profile for sites categorized as artificial fill, we 
developed generic velocity models that can be used in Boston. Although $\mathrm{V}_{\mathrm{S}}$ data collected at bedrock sites in the region indicate a $\mathrm{V}_{\mathrm{Sb}}$ of approximately $2000 \mathrm{~m} / \mathrm{s}$, the comparison of surface/input amplification ratios at the Northeastern University (NEU) vertical seismometer array indicate that the assumption of $\mathrm{V}_{\mathrm{Sb}}=3000 \mathrm{~m} / \mathrm{s}$ results in a better fit with the observed recordings. At the NEU vertical array site, a relatively deep soil site in Boston, the bedrock depth was observed at $50 \mathrm{~m}$, versus the $30 \mathrm{~m}$ predicted by the depth-to-bedrock model. This inaccuracy of the model resulted in a shift in the fundamental period for the site but similar amplifications. Because expected maximum soil shear strains are relatively low $(\sim 0.03 \%)$ for the generic soil profile used herein, equivalent linear methods are appropriate. Linear site response analysis were sufficient to predict the soil amplification at the NEU site for the observed ground shaking from the Mineral Earthquake. Finally, the results from this study provide evidence that the mean short-period and mean intermediate-period amplification used in design codes as $\mathrm{F}_{\mathrm{a}}$ and $\mathrm{F}_{\mathrm{v}}$ site coefficients may underpredict soil amplification in strong impedance contrast environments such as Boston, particularly underprediction may occur when code-based Fa is applied to shallow soil columns and when code-based Fa and Fv aare pplied to deep soil columns..

\section{Acknowledgements}

We thank Jing Zhu for her help in generating the maps. We thank Erkan Yilar for his reviews. We also thank John Ebel of Boston College and Ehsan Kianirad of Haley \& Aldrich for their reviews and the discussions that followed. Helpful feedback from two anonymous reviewers, William Stephenson and Charles Mueller from the USGS is gratefully acknowledged. This work draws on many smaller projects completed at Tufts University by undergraduate and graduate students under the supervision of Prof. Laurie Baise that had not previously been published, specifically Eric Johnson, who developed the stratigraphic database, and Alex Grant and Alex Testa, who initially developed the design ground motions for Boston. This work was in part funded by the Defense Threat Reduction Agency under contract AFRL-FA8718-09-C-0051 and the U.S. Geological Survey through Award No. G14AP0006. We thank Dr. Philip Cole and Mr. James Lewkowicz for their support. We also thank Mishac Yegian at Northeastern University for his foresight in installing the NEU vertical array. 


\section{References}

American Society of Civil Engineers [ASCE] (2013). Minimum Design Loads for Buildings and Other Structures (Standards ASCE/SEI 7-10). American Society of Civil Engineers, Reston, Virginia, $636 \mathrm{pp}$.

Baise, L. G., Glaser, S. D., and Dreger, D. (2003). Site response at Treasure and Yerba Buena Islands, California. Journal of Geotechnical and Geoenvironmental Engineering, 129(5): 415-426.

Banab, K. K., Kolaj, M., Motazedian, D., Sivathayalan, S., Hunter, J. A., Crow, H. L., Pugin, A. J.-M., Brooks, G. R., and Pyne, M. (2012). Seismic site response analysis for Ottawa, Canada: A comprehensive study using measurements and numerical simulations. Bulletin of the Seismological Society of America, 102(5): 1976-1993.

Barosh, P. J., and Woodhouse, D. (2011/2012). Geology of the Boston Basin. Civil Engineering Practice, 26\&27: 100-236.

Bonilla, L. F., Steidl, J. H., Gariel, J. C., and Archuleta, R. J. (2002). Borehole response studies at the Garner Valley downhole array, southern California. Bulletin of the Seismological Society of America, 92(8): 3165-3179.

Boore, D. M. (2005). SMSIM---Fortran programs for simulating ground motions from earthquakes: Version 2.3---a revision of OFR 96-80-A. U. S. Geological Survey Open-File Report 2000-509, revised 15 August 2005, 55 pp.

Boston Society of Civil Engineers [BSCE] (1961). Boring data from Greater Boston. Boston Society of Civil Engineers, Boston, Massachusetts.

Brankman, C.M. and Baise, L.G. (2008). Liquefaction Susceptibility Mapping in Boston, Massachusetts, Engineering and Environmental Geoscience, XIV(1): 1-16.

Brocher, T. M. (2005). Empirical relations between elastic wavespeeds and density in the Earth's crust. Bulletin of the Seismological Society of America, 95(6): 2081-2092.

Building Seismic Safety Council [BSSC] (2009). NEHRP recommended provisions for seismic regulations for new buildings and other structures, 2009 Edition. FEMA P-750 Report, Federal Emergency Management Agency, Washington, D.C.

Dobry, R., Borcherdt, R. D., Crouse, C. B., Idriss, I. M., Joyner, W. B., Martin, G. R., Power, M. S., Rinne, E. E., and Seed, R. B. (2000). New site coefficients and site classification system used in recent building seismic code provisions. Earthquake Spectra, 16(1): 41-67.

Dobry, R., Liu, L., and Stokoe, K. H. (1996). Queensboro Bridge in New York City: geotechnical seismic hazard assessment. 11th World Conference on Earthquake Engineering, Acapulco, Mexico, 23-28 June 1996. 
FitzGerald, D. M., Buynevich, I. V., Fenster, M. S., Kelley, J. T., and Belknap, D. F. (2005). Coarse-grained sediment transport in northern New England estuaries: a synthesis, pp. 195213 in High Resolution Morphodynamics and Sedimentary Evolution of Estuaries, D. M. FitzGerald and J. Knight (eds.), Springer Netherlands.

Glaser S. D., and Baise L. G. (2000). System identification estimation of soil properties at the Lotung site. Soil Dynamics and Earthquake Engineering, 19(7): 521-531.

Goulet, C. A., Kishida, T., Ancheta, T. D., Cramer, C. H., Darragh, R. B., Silva, W. J., Hashash, Y. M. A., Harmon, J., Stewart, J. P., Wooddell, K. E., and Youngs, R. R. (2014). PEER NGA-East database. PEER Report 2014/17, Pacific Earthquake Engineering Research Center, University of California Berkeley, Berkeley, California.

Haley \& Aldrich, Inc. (1991). Final Geotechnical Engineering Report, Central Artery (I93)/Tunnel (I-90) Project, Design Sections D007A and D007C, Boston, Massachusetts. Haley \& Aldrich, Inc., Cambridge, Massachusetts.

Hashash, Y. M., Kottke, A. R., Stewart, J. P., Campbell, K. W., Kim, B., Moss, C., and Silva, W. J. (2014). Reference rock site condition for Central and Eastern North America. Bulletin of the Seismological Society of America, 104(2): 684-701.

Hayles, K. E., Ebel, J. E., and Urzua, A. (2001). Microtremor measurements to obtain resonant frequencies and ground shaking amplification for soil sites in Boston. Civil Engineering Practice, 16(2): 17-36.

Hines, E. M., Baise, L. G., and Swift, S. (2011). Ground motion suite selection for Eastern North America. Journal of Structural Engineering, 137(3): 358-366.

Hough, S. E. (2012). Initial assessment of the intensity distribution of the $2011 \mathrm{M}_{\mathrm{w}} 5.8 \mathrm{Mineral}$, Virginia earthquake. Seismol. Res. Lett., 83(4): 649-657.

Idriss, I. M., and Sun, J. I. (1991). SHAKE91: a computer program for conducting equivalent linear seismic response analyses of horizontally layered soil deposits. User's Manual, University of California Davis, Davis, California.

Johnson, E. G. (1989). Geotechnical characteristics of the Boston area. Civil Engineering Practice, 4(1): 53-64.

Kaklamanos, J., Bradley, B. A., Thompson, E. M, and Baise, L. G. (2013). Critical parameters affecting bias and variability in site-response analyses using KiK-net downhole array data. Bulletin of the Seismological Society of America, 103(3): 1733-1749.

Kaklamanos, J., Baise, L. G., Thompson, E. M, and Dorfmann, L. (2015). Comparison of 1D linear, equivalent-linear, and nonlinear site response models at six KiK-net validation sites. Soil Dynamics and Earthquake Engineering, 69: 207-219. 
Kishida, T., Wehling, T. M., Boulanger, R. W., Driller, M. W., and Stokoe, K. H. (2009). Dynamic properties of highly organic soils from Montezuma Slough and Clifton Court. Journal of Geotechnical and Geoenvironmental Engineering, 135(4): 525-532.

Kottke, A. R., and Rathje, E. M. (2013). Technical manual for SigmaSpectra, available at http://nees.org/resources/sigmaspectra [accessed Aug. 2015].

Kramer, S. L. (1996). Geotechnical Earthquake Engineering. Prentice Hall, Upper Saddle River, N. J., 653 pp.

Lambe, T. W., and Whitman, R. V. (1969). Soil mechanics. John Wiley \& Sons, Inc., New York, $553 \mathrm{pp}$.

Molnar, S., Cassidy, J. F., and Dosso, S. E. (2004). Site response in Victoria, British Columbia, from spectral ratios and 1D modeling. Bulletin of the Seismological Society of America, 94(3): 1109-1124.

Ordóñez, G. A. (2014). SHAKE2000: a computer program for the 1-D analysis of geotechnical earthquake engineering problems. User's Manual, GeoMotions, LLC, Lacey, Washington.

Petersen, M. D., Frankel, A. D., Harmsen, S. C., Mueller, C. S., Haller, K. M., Wheeler, R. L., Wesson, R. L., Zeng, Y., Boyd, O. S., Perkins, D. M., Luco, N., Field, E. H., Wills, C. J., and Rukstales, K. S. (2008). Documentation for the 2008 Update of the Unites States National Seismic Hazard Maps. U.S. Geological Survey Open-File Report 2008-1128, 61 pp.

Santagata, M., and Kang, Y. (2007). Effects of geologic time on the initial stiffness of clays. Engineering Geology, 89: 98-111.

Schnabel, P. B., Lysmer, J., and Seed, H. B. (1972). SHAKE: a computer program for earthquake response analysis of horizontally layered sites. Report No. UCB/EERC-72/12, Earthquake Engineering Research Center, University of California Berkeley, Berkeley, California.

Seed, H. B., and Idriss, I. M. (1970). Soil moduli and damping factors for dynamic response analyses, Report UCB/EERC 70-10, Earthquake Engineering Research Center, University of California, Berkeley, California, $40 \mathrm{pp}$.

Seed, H. B., Romo, M. P., Sun, J. I., Jaime, A., and Lysmer, J. (1988). The Mexico earthquake of September 19, 1985-Relationships between soil conditions and earthquake ground motions. Earthquake Spectra, 4(4): 687-729.

Somerville, P., and Collins, N. (2003). Ground motion time histories for use in performance based seismic engineering. Final Report, U.S. Geological Survey Award Number 01HQGR0154, URS Group, Inc., Pasadena, California. 
Vucetic, M., and Dobry, R. (1991). Effect of soil plasticity on cyclic response. Journal of Geotechnical Engineering, 117(1): 89-107.

Woodhouse, D., and Barosh, P. J. (2011/2012). Geotechnical factors in Boston. Civil Engineering Practice, 26\&27: 237-263

Yegian. M. K. (2014). Seismic recording station at Northeastern University, Boston, Massachusetts. Personal communication.

Zalachoris, G., and Rathje, E.M. (2015). Evaluation of one-dimensional site response techniques using borehole arrays. J. Geotech. Geoenv. Eng, 141(12): 04015053. 


\section{Tables}

607 Table 1: Generalized soil conditions in Boston (sites categorized as artificial fill in the surficial geology map)

\begin{tabular}{ll}
\hline Parameter * & Range \\
\hline Height of soil column $(\mathrm{H})$ & $10-80 \mathrm{~m}$ \\
Shear-wave velocity of the soil $\left(\mathrm{V}_{\mathrm{Ss}}\right)$ & $100-500 \mathrm{~m} / \mathrm{s}$ \\
Shear-wave velocity of the bedrock $\left(\mathrm{V}_{\mathrm{Sb}}\right)$ & $1750-2250 \mathrm{~m} / \mathrm{s}$ \\
Density of the soil $\left(\rho_{\mathrm{s}}\right)$ & $1.4-1.9 \mathrm{~g} / \mathrm{cm}^{3}$ \\
Density of the bedrock $\left(\rho_{\mathrm{b}}\right)$ & $2.75 \mathrm{~g} / \mathrm{cm}^{3}$ \\
Quality factor $(\mathrm{Q})$ & $10-30$ \\
\hline * In the parameter column, the subscript $s$ is used to denote a \\
property of the soil, and the subscript $b$ is used to denote a \\
property of the bedrock.
\end{tabular}

Table 2: Earthquake events and number of records for SigmaSpectra

\begin{tabular}{llllllllll}
\hline $\begin{array}{l}\text { Earthquake } \\
\text { Name }\end{array}$ & Date & $\begin{array}{l}\text { Moment } \\
\text { Magnitude, } \\
\mathrm{M}_{\mathrm{w}}\end{array}$ & $\begin{array}{l}\text { Strike } \\
(\mathrm{deg})\end{array}$ & $\begin{array}{l}\text { Dip } \\
(\mathrm{deg})\end{array}$ & $\begin{array}{l}\text { Rake } \\
(\mathrm{deg})\end{array}$ & $\begin{array}{l}\text { Epicenter } \\
\text { Latitude } \\
(\mathrm{deg})\end{array}$ & $\begin{array}{l}\text { Epicenter } \\
\text { Longitude } \\
(\mathrm{deg})\end{array}$ & $\begin{array}{l}\text { Hypocentral } \\
\text { depth (km) }\end{array}$ & $\begin{array}{l}\text { No. } \\
\text { records }\end{array}$ \\
\hline Saguenay, Quebec & $11 / 25 / 1988$ & 5.9 & 189 & 39 & 135 & 48.07 & -71.27 & 24 & 10 \\
Au Sable Forks, N.Y. & $04 / 20 / 2002$ & 5.1 & 341 & 15 & 89 & 44.51 & -73.7 & 11 & 2 \\
Riviere-du-Loup, Quebec & $03 / 06 / 2005$ & 4.7 & 170 & 60 & 80 & 47.75 & -69.73 & 13 & 4 \\
Val-des-Bois, Quebec & $06 / 23 / 2010$ & 5.0 & 145 & 60 & 80 & 45.86 & -75.46 & 22 & 20 \\
Mineral, Virginia & $08 / 23 / 2011$ & 5.8 & 175 & 45 & 65 & 37.94 & -77.93 & 6 & 7 \\
\hline
\end{tabular}

\section{2}

\section{3}

614

Table 3: Suite of motions and scaling factors for input to site response analyses

\begin{tabular}{lllllll}
\hline Earthquake Name & Station Name & $\begin{array}{l}\text { Epicentral } \\
\text { distance } \\
(\mathrm{km})\end{array}$ & $\begin{array}{l}\text { Site } \\
\text { Latitude } \\
(\mathrm{deg})\end{array}$ & $\begin{array}{l}\text { Site } \\
\text { Longitude } \\
(\mathrm{deg})\end{array}$ & PGA $(g)$ & $\begin{array}{l}\text { Scaling } \\
\text { Factor }\end{array}$ \\
\hline Saguenay, Quebec & CN.LMBQ.HNN & 95.5 & 47.6553 & -70.1527 & 0.060 & 0.66 \\
Saguenay, Quebec & CN.QCQ.HNN & 143.5 & 46.7791 & -71.2760 & 0.051 & 2.01 \\
Saguenay, Quebec & CN.ROUQ.HNN & 116.1 & 47.4753 & -69.9966 & 0.040 & 1.63 \\
Saguenay, Quebec & CN.STPQ.HNN & 125.3 & 47.5262 & -69.8049 & 0.046 & 1.28 \\
Val-des-Bois, Quebec & CN.OT012.HNE & 59.2 & 45.3942 & -75.7167 & 0.031 & 2.59 \\
Val-des-Bois, Quebec & CN.OTRS.HNN & 49.3 & 45.4603 & -75.4962 & 0.064 & 1.29 \\
Mineral, Virginia & NP.2555.HNN & 121.6 & 38.9510 & -77.3360 & 0.040 & 2.13 \\
Mineral, Virginia & US.CBN.HN220 & 57.5 & 38.2046 & -77.3732 & 0.133 & 0.69 \\
\hline
\end{tabular}


Table 4: Soil types used in SHAKE

\begin{tabular}{|c|c|c|c|}
\hline $\begin{array}{l}\text { Depth } \\
(\mathrm{m})\end{array}$ & Layer type & $\begin{array}{l}\text { Unit weight } \\
\left(\mathrm{kN} / \mathrm{m}^{3}\right)\end{array}$ & Modulus-reduction and damping curve \\
\hline $0-3$ & Fill & 20 & Seed and Idriss (1970): Sand \\
\hline $3-6$ & Organics & 17 & Vucetic and Dobry (1991): Clay, PI = 30 \\
\hline $6-15$ & Sand and gravel & 19 & Seed and Idriss (1970): Sand \\
\hline $15-\mathrm{H}^{*}$ & Clay & 18.5 & Vucetic and Dobry (1991): Clay, PI = 30 \\
\hline- & Bedrock & 27 & Linear \\
\hline
\end{tabular}


Figures

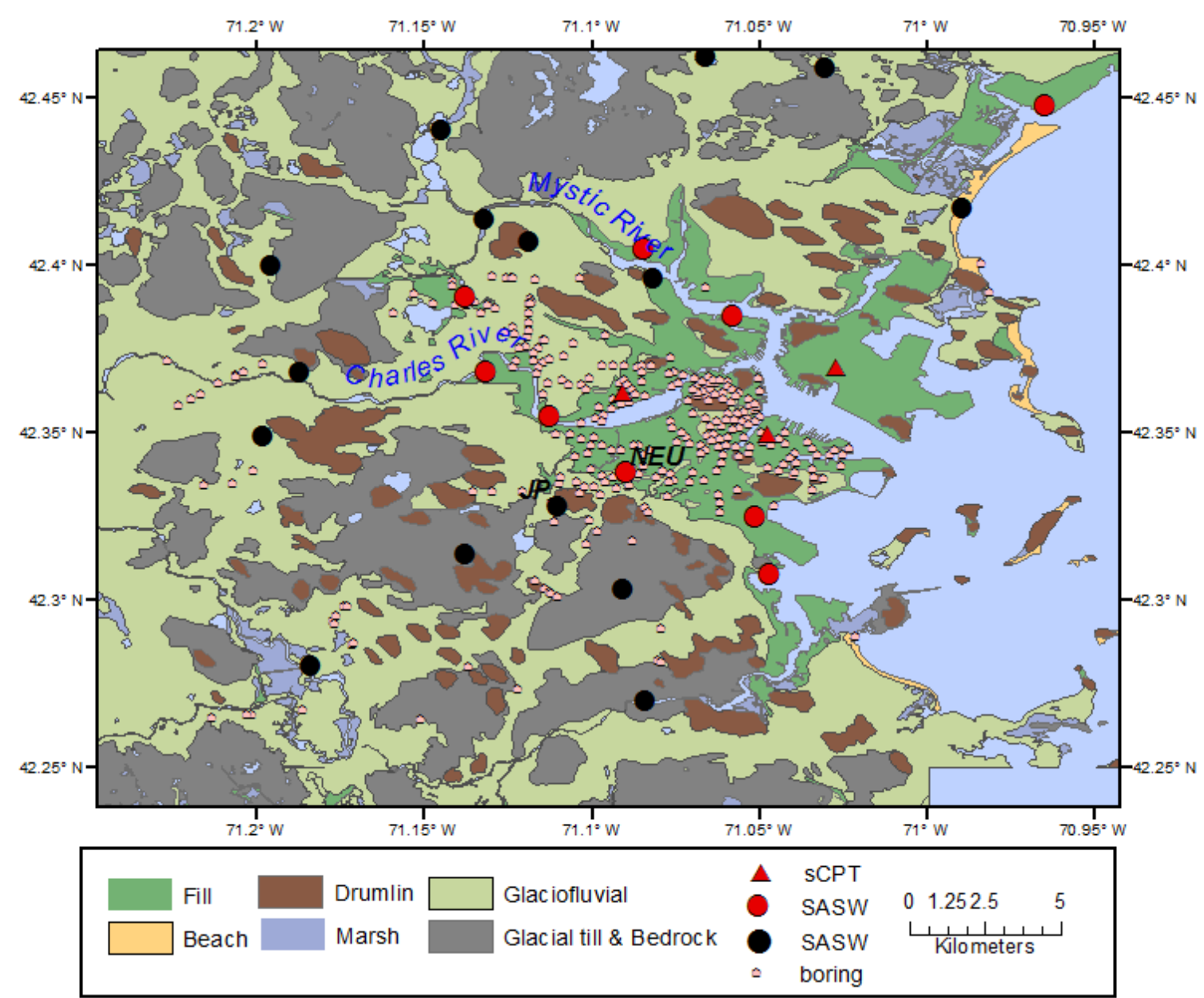

Figure 1: Boston surficial geology map (Brankman and Baise, 2008) with locations of $V_{S}$ measurements. Red markers signify SASW measurements in the artificial fill that are used in this study, and black markers signify SASW measurements in other geologic units. 


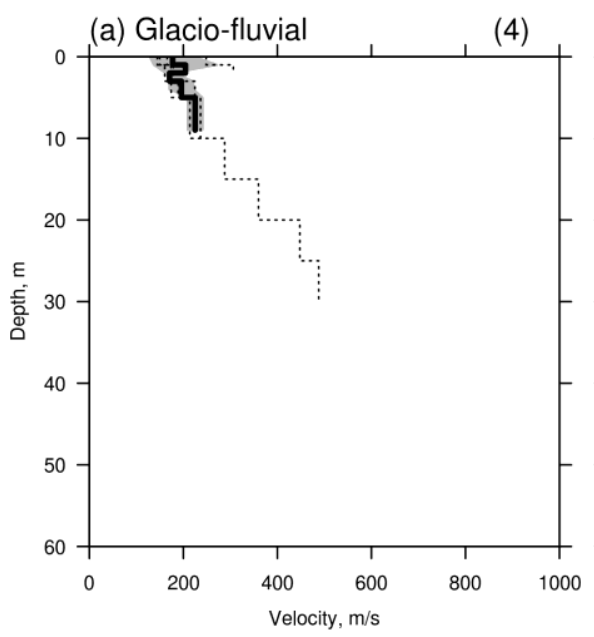

(b) Fill

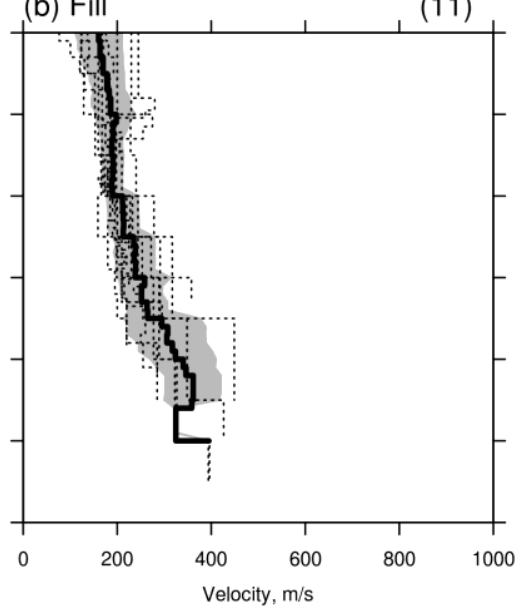

(c) Bedrock

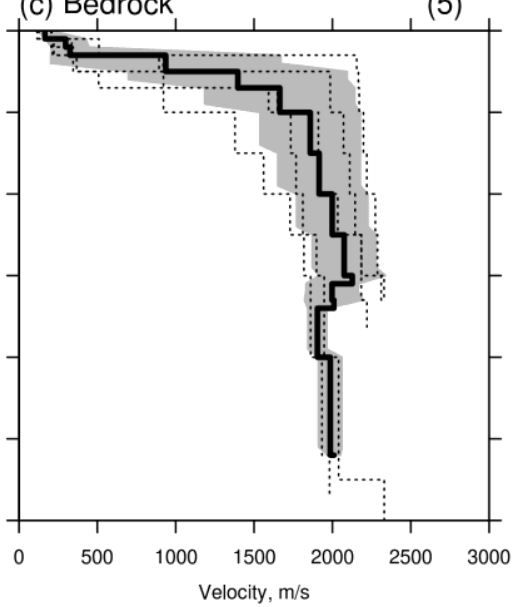

Figure 2: Generic shear-wave velocity profiles for glaciofluvial deposits, artificial fill, and bedrock sites. Dotted lines show individual profiles, black lines show mean profiles, and gray bands indicate $95 \%$ confidence intervals. The number in parenthesis indicates how many measured profiles were used in each category.

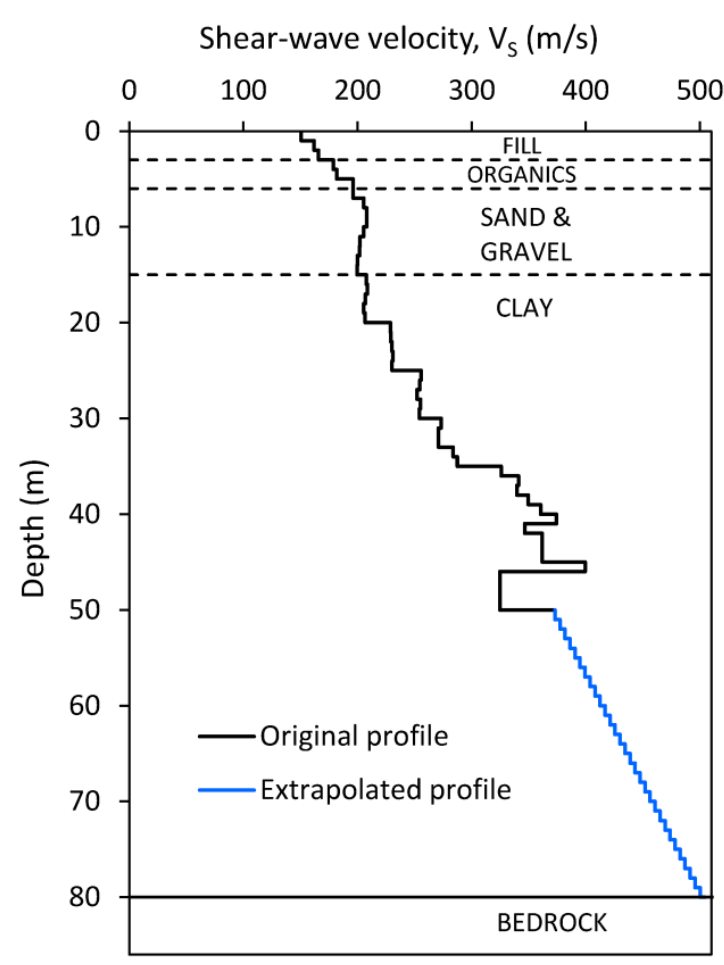

Figure 3: Generic shear-wave velocity profile and stratigraphy for sites classified as artificial fill. The profile is truncated at the depth $\mathrm{H}$ of the soil-bedrock interface (here, the profile is drawn for the maximum possible bedrock depth of $80 \mathrm{~m}$ ). Properties of the soil layers are given in Table 4. 


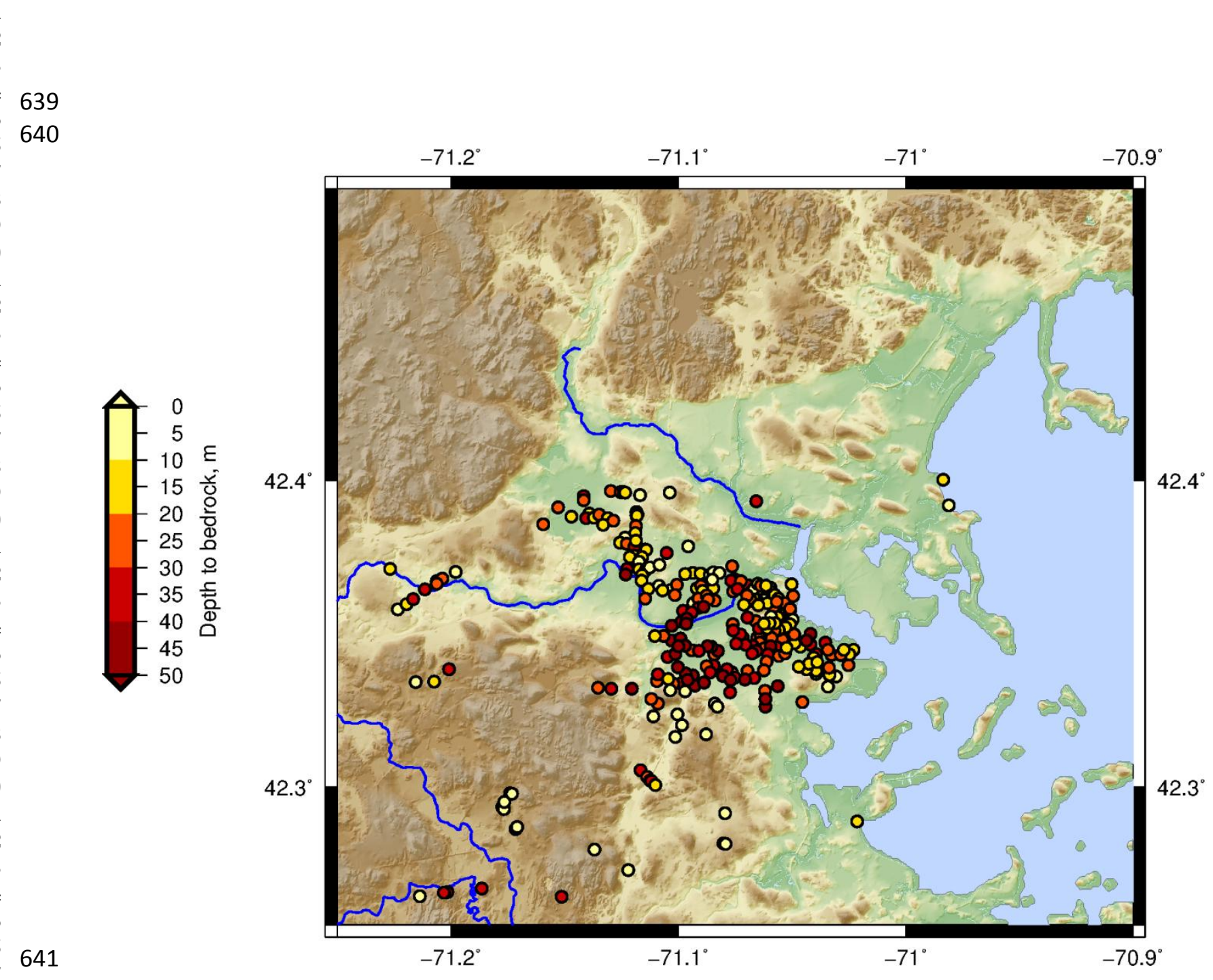

Figure 4: Database of geotechnical boreholes that reach bedrock. The background shows the 643 topography, where brown represents high elevation and green represents low elevation. The 644 sediment/rock boundary can be observed at the base of the brown hills. 
Figure 5: Model of the bedrock depth. The bedrock depth is shown over the digital elevation model (DEM) hillshade map to illustrate elevation. The NEU and JP stations are also labeled.

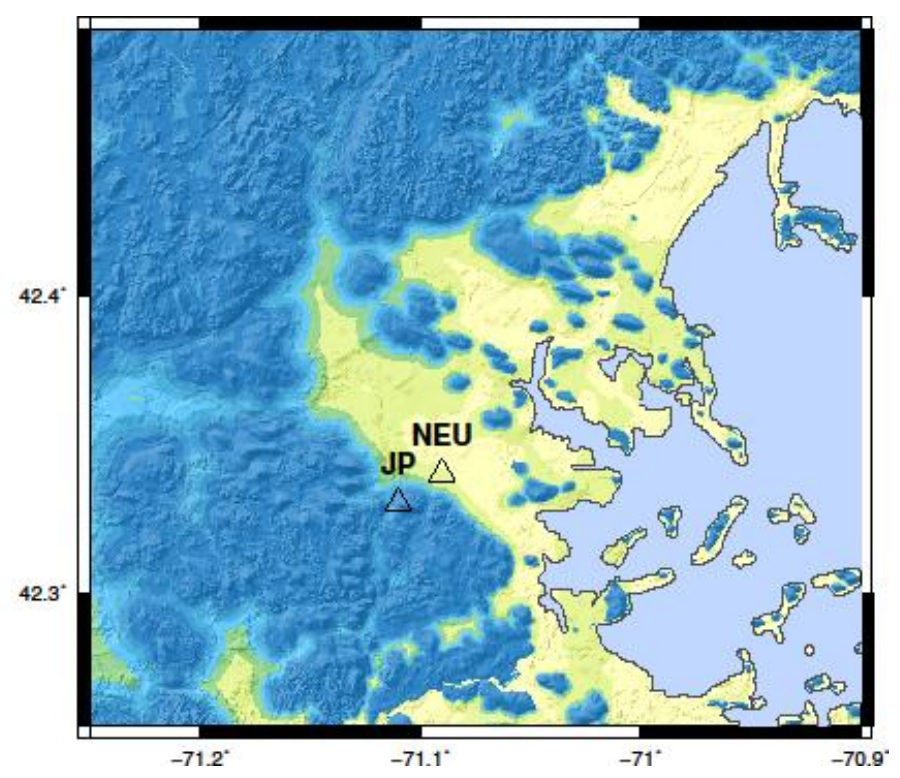


(a) $L: V_{s b}=2000 \mathrm{~m} / \mathrm{s}, Q=15$

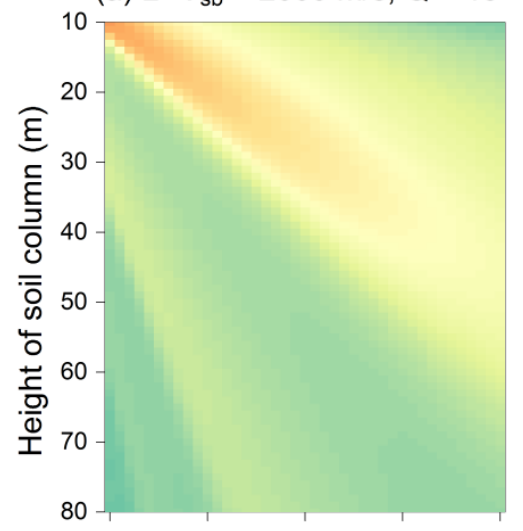

(d) $L: V_{s b}=2000 \mathrm{~m} / \mathrm{s}, Q=15$

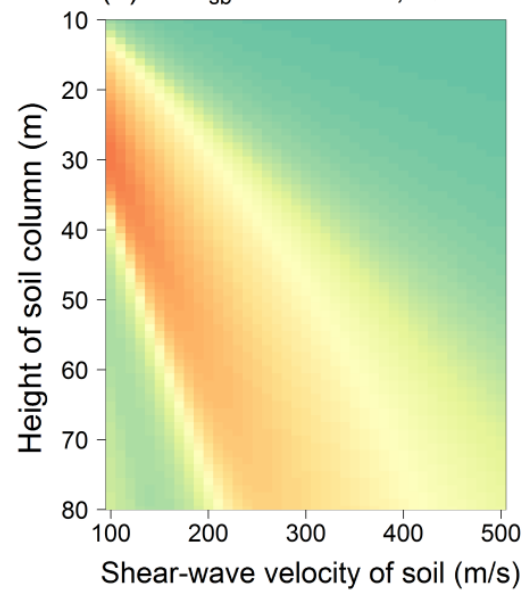

(b) $L: V_{s b}=2000 \mathrm{~m} / \mathrm{s}, Q=30$

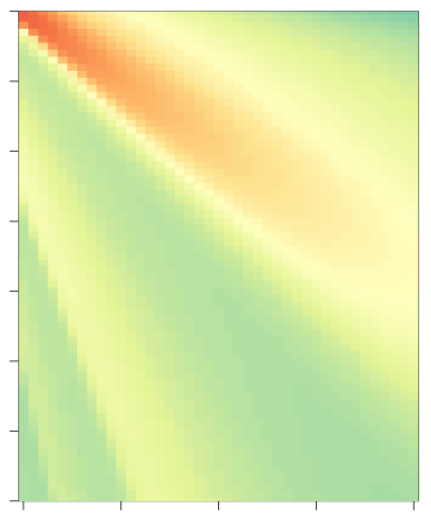

(e) $L: V_{s b}=2000 \mathrm{~m} / \mathrm{s}, Q=30$

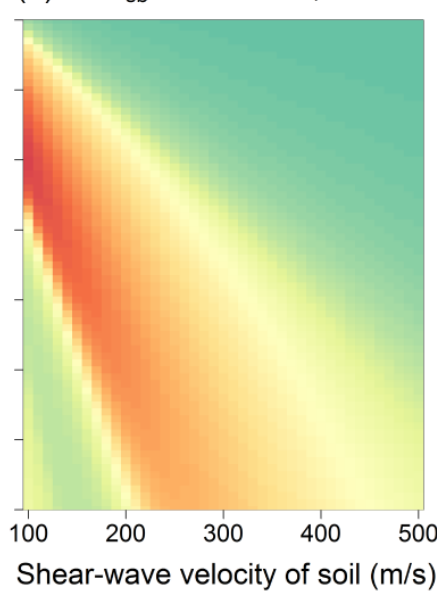

(c) $E Q L: V_{s b}=2000 \mathrm{~m} / \mathrm{s}$
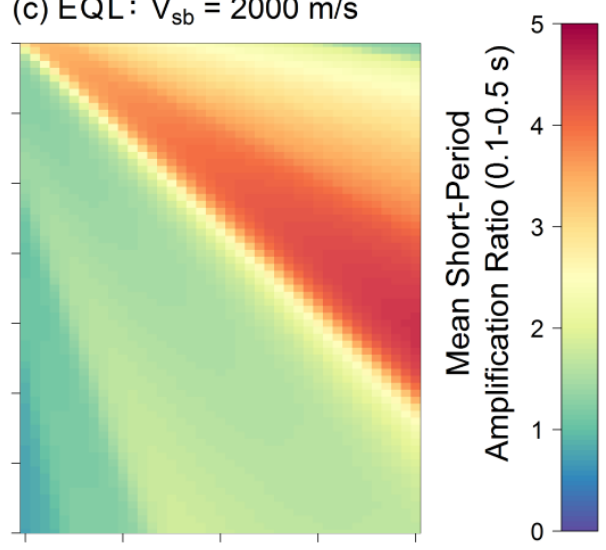

(f) $E Q L: V_{s b}=2000 \mathrm{~m} / \mathrm{s}$
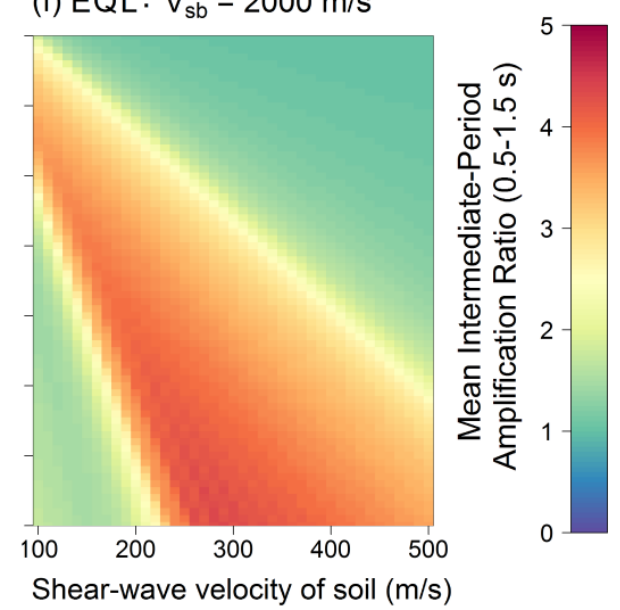

Figure 6: Contour plots of mean amplifications for soil profiles with constant $\mathrm{V}_{\mathrm{Ss}}$ and thickness $\mathrm{H}$, overlying bedrock with $\mathrm{V}_{\mathrm{Sb}}=2000 \mathrm{~m} / \mathrm{s}$. The top row displays the results for the mean shortperiod amplification ratio $(0.1-0.5 \mathrm{~s})$ for the following analyses: (a) linear $(\mathrm{L})$ with $\mathrm{Q}=15$, (b) linear with $\mathrm{Q}=30$, and (c) equivalent linear (EQL). The bottom row displays the results for the mean intermediate-period amplification ratio $(0.5-1.5 \mathrm{~s})$ for $(\mathrm{d})$ linear with $\mathrm{Q}=15$, (e) linear with $\mathrm{Q}=30$, and (f) equivalent linear. 
(a) $L: V_{s b}=3000 \mathrm{~m} / \mathrm{s}, Q=15$

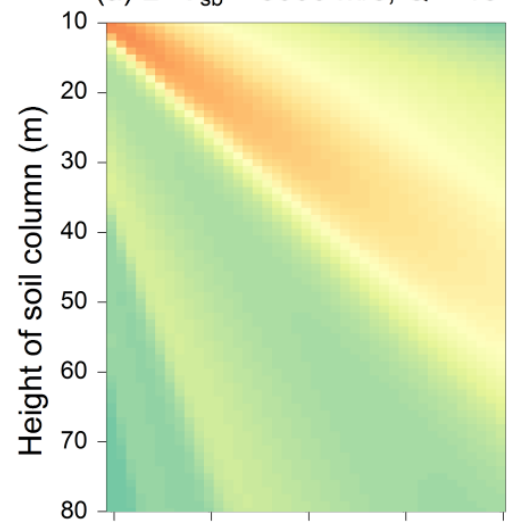

(d) $L: V_{s b}=3000 \mathrm{~m} / \mathrm{s}, Q=15$

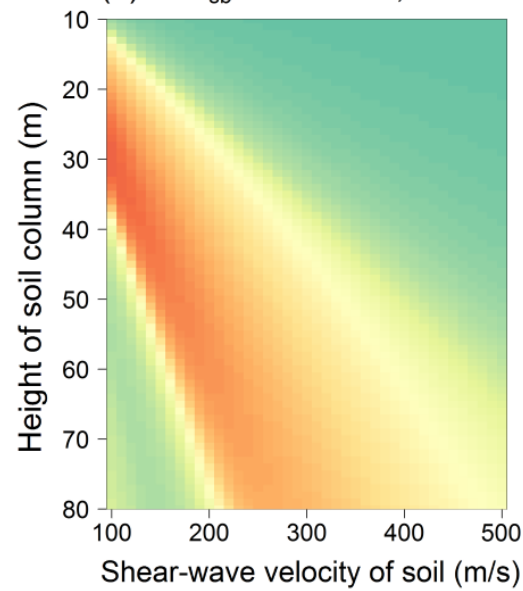

(b) $L: V_{s b}=3000 \mathrm{~m} / \mathrm{s}, Q=30$

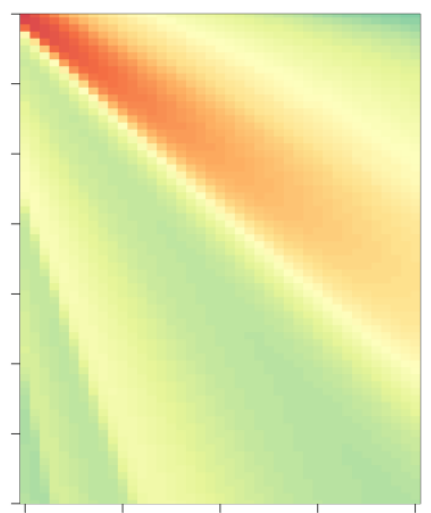

(e) $L: V_{s b}=3000 \mathrm{~m} / \mathrm{s}, Q=30$

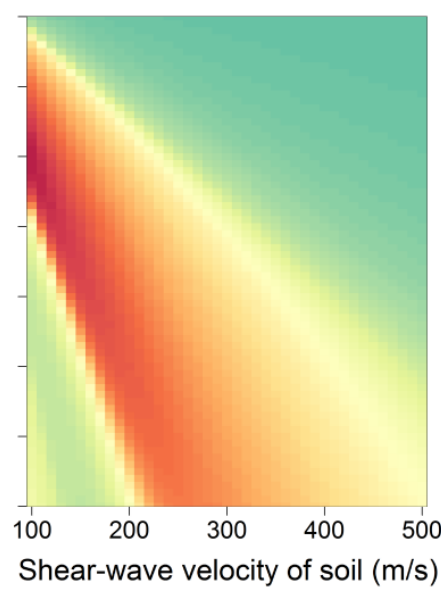

(c) $E Q L: V_{s b}=3000 \mathrm{~m} / \mathrm{s}$
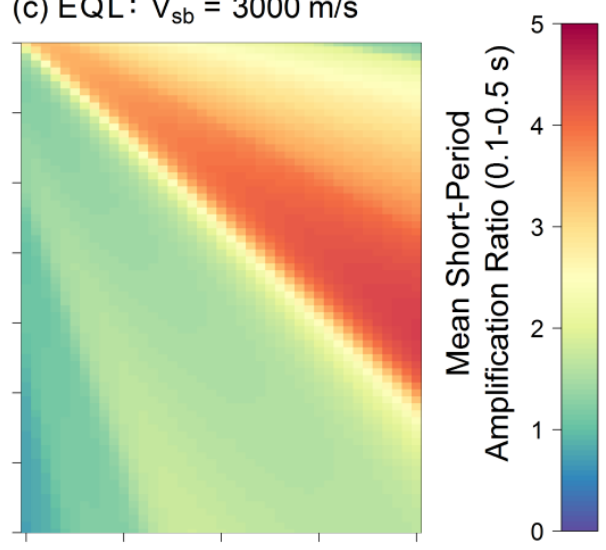

(f) $E Q L: V_{s b}=3000 \mathrm{~m} / \mathrm{s}$
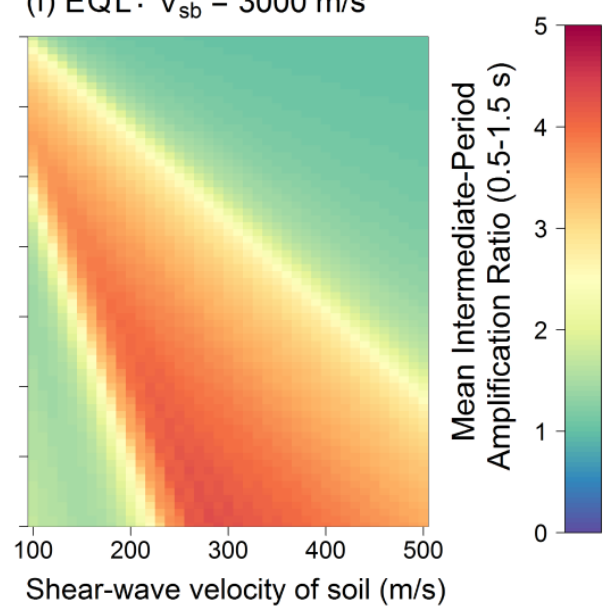

Figure 7: Contour plots of mean amplifications for soil profiles with constant $\mathrm{V}_{\mathrm{Ss}}$ and thickness $\mathrm{H}$, overlying bedrock with $\mathrm{V}_{\mathrm{Sb}}=3000 \mathrm{~m} / \mathrm{s}$. The top row displays the results for the mean shortperiod amplification ratio $(0.1-0.5 \mathrm{~s})$ for the following analyses: (a) linear (L) with $\mathrm{Q}=15$, (b) linear with $\mathrm{Q}=30$, and (c) equivalent linear (EQL). The bottom row displays the results for the mean intermediate-period amplification ratio $(0.5-1.5 \mathrm{~s})$ for $(\mathrm{d})$ linear with $\mathrm{Q}=15$, (e) linear with $\mathrm{Q}=30$, and (f) equivalent linear. 
(a) Linear

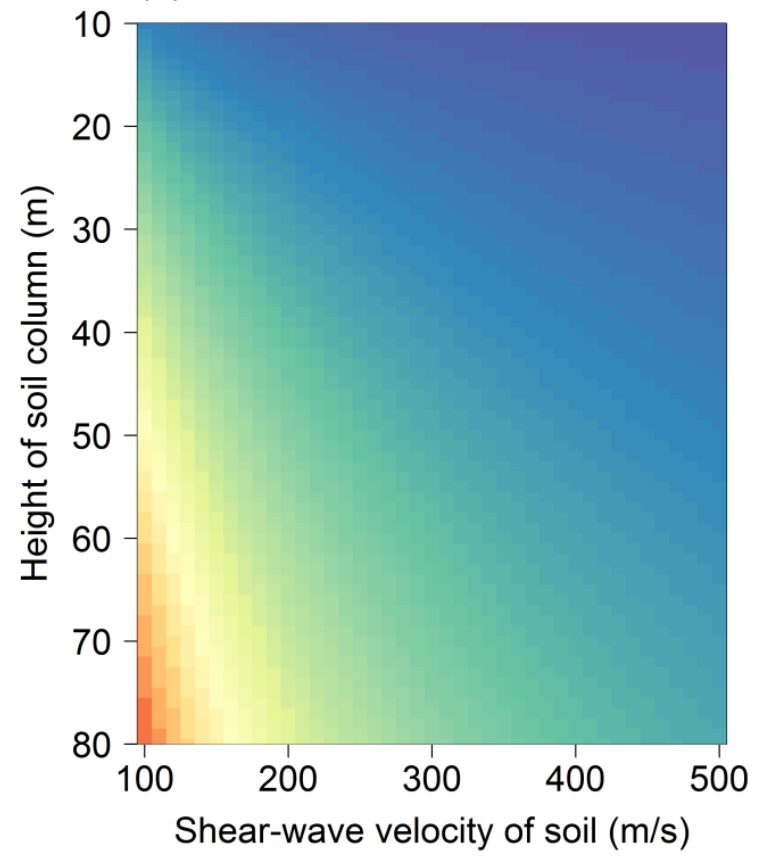

(b) Equivalent-Linear
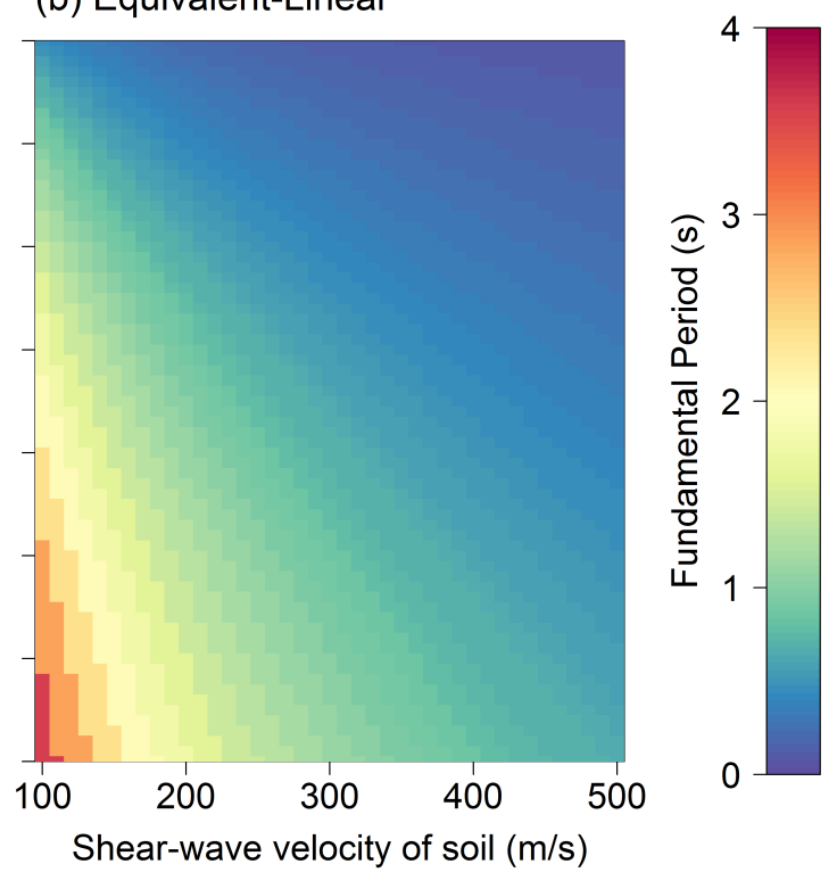

Figure 8: Contour plots of the fundamental period of the site response transfer function for (a) linear and (b) equivalent-linear analyses.

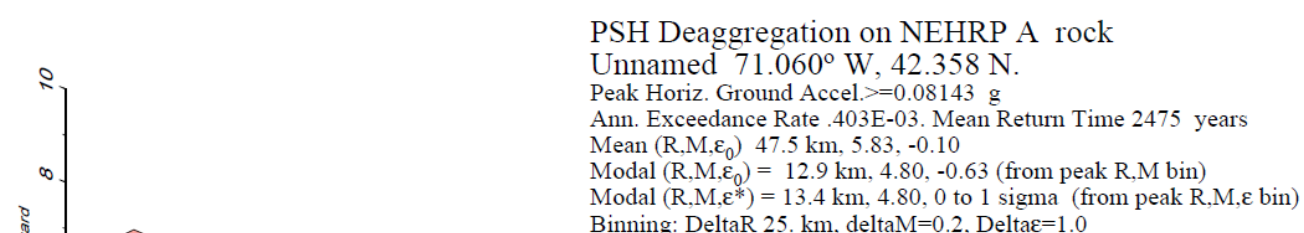

Binning: DeltaR $25 . \mathrm{km}$, deltaM $=0.2$. Delta $\varepsilon=1.0$

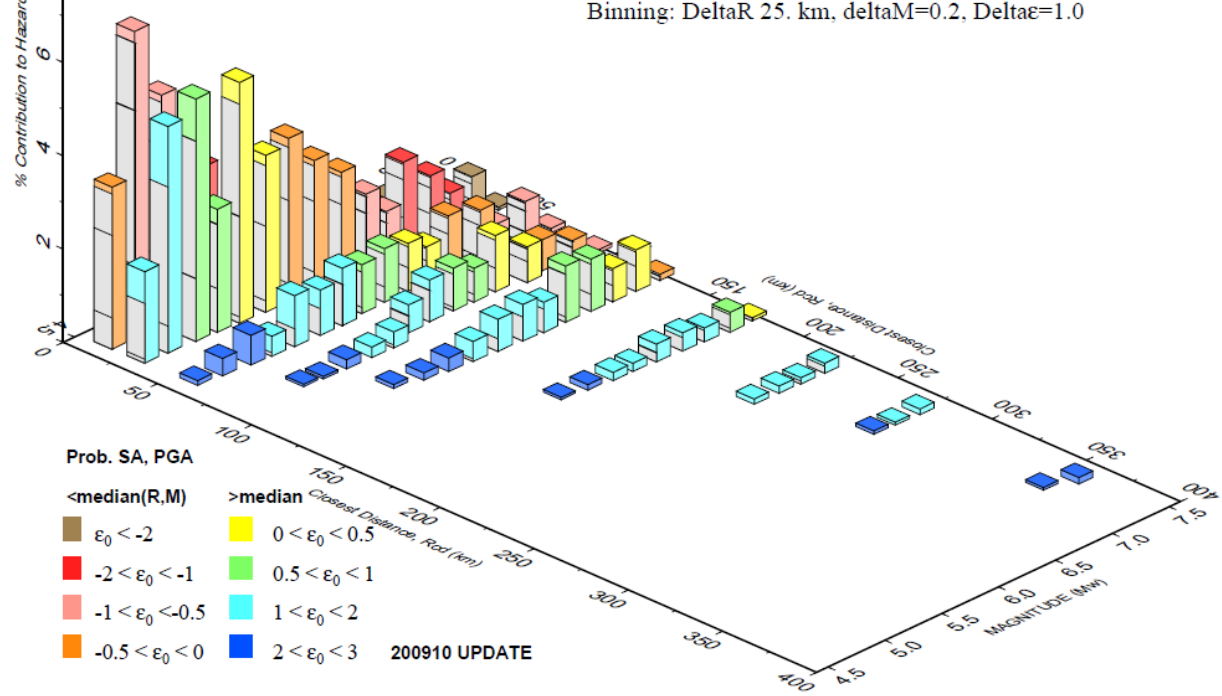

655 Figure 9: Deaggregation plot of seismic hazard in Boston (2\% probability exceedance in 50 656 years) for NEHRP Site Class A, resulting in PGA of 0.081g (from the USGS National Seismic 657 Hazards Mapping Project website; Petersen et al., 2008). 


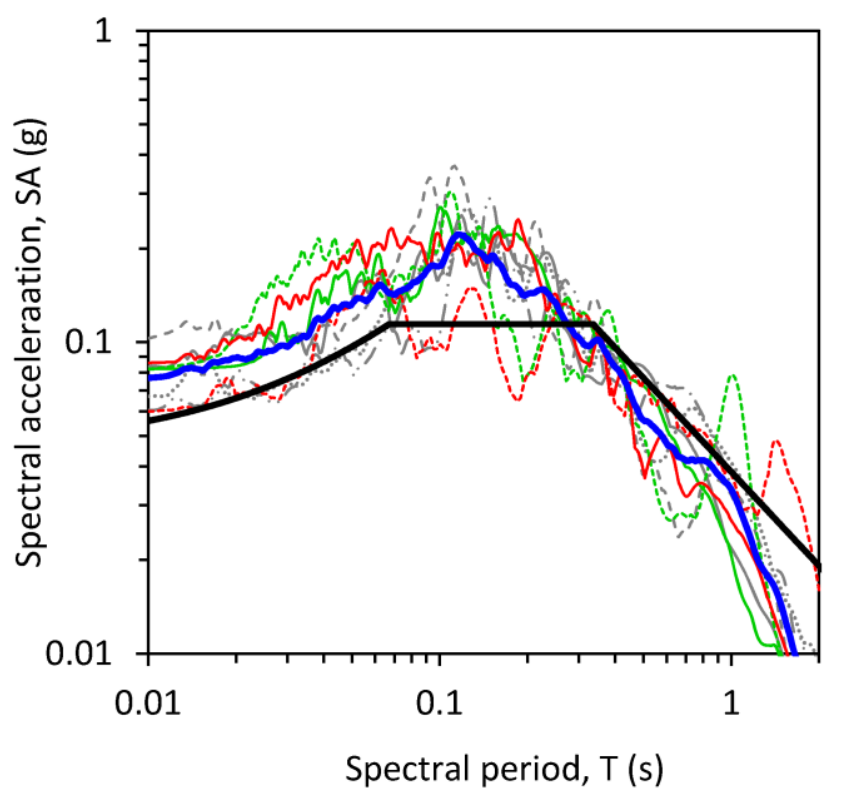

Figure 10: Design response spectrum (NEHRP site class A) and suite of design ground motions used in the equivalent-linear site response analyses.

_- Saguenay CN.LMBQ.HNN

- - - - Saguenay CN.QCQ.HNN

............. Saguenay CN.ROUQ.HNN

-..-.. Saguenay CN.STPQ.HNN

— Val-des-Bois CN.OT012.HNE

- Val-des-Bois CN.OTRS.HNN

Mineral NP.255.HNN

- Mineral US.CBN.HN2.20

Median SA of Suite

Design Spectrum (Site Class A) 
(a)

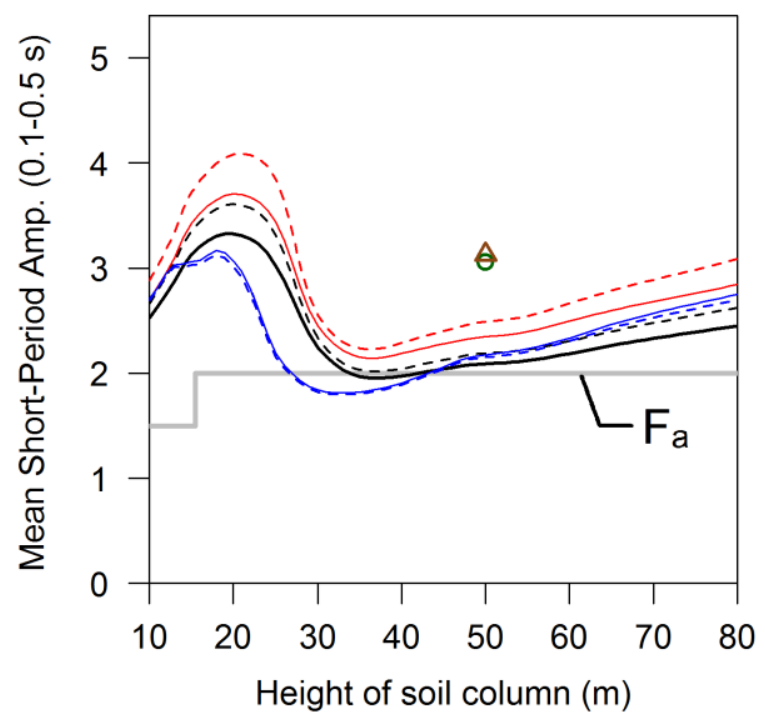

(c)

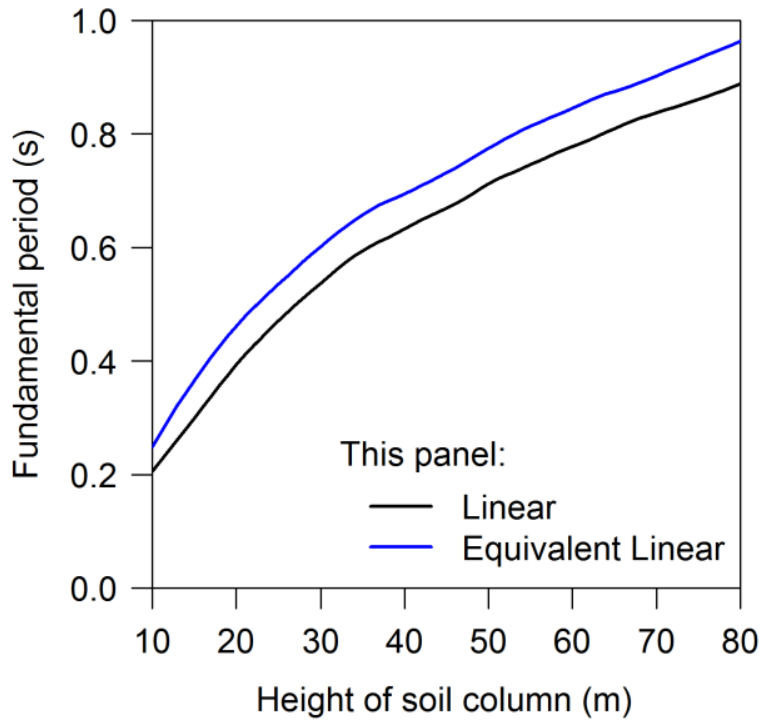

(b)

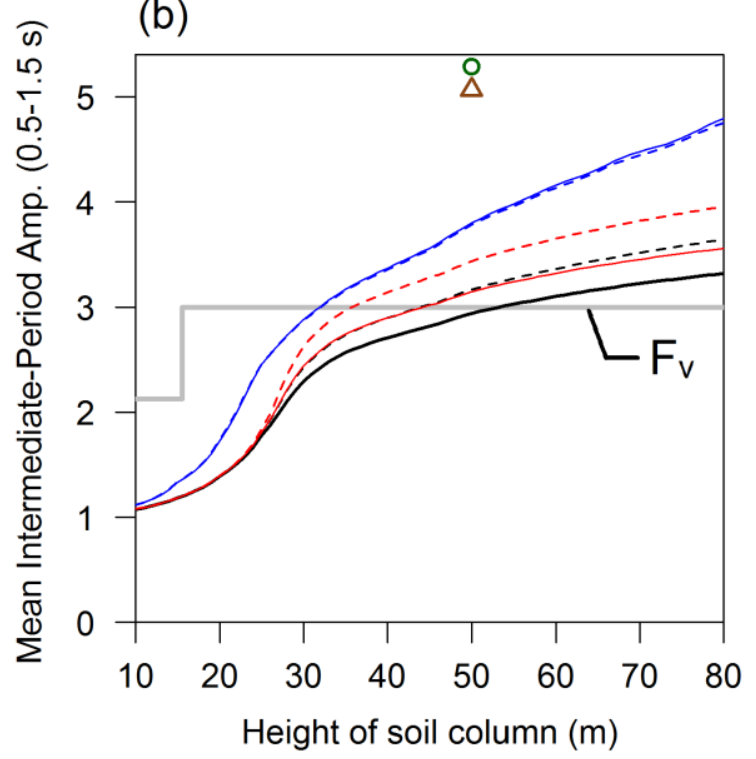

Panels (a) and (b):

- Linear, $V_{\mathrm{sb}}=2000 \mathrm{~m} / \mathrm{s}, \mathrm{Q}=15$

-..- Linear, $V_{\mathrm{sb}}=3000 \mathrm{~m} / \mathrm{s}, \mathrm{Q}=15$

Linear, $V_{\mathrm{sb}}=2000 \mathrm{~m} / \mathrm{s}, \mathrm{Q}=30$

Linear, $V_{\mathrm{sb}}=3000 \mathrm{~m} / \mathrm{s}, \mathrm{Q}=30$

Equivalent Linear, $V_{\mathrm{sb}}=2000 \mathrm{~m} / \mathrm{s}$

Equivalent Linear, $V_{\mathrm{sb}}=3000 \mathrm{~m} / \mathrm{s}$

Site Coefficients, $F_{a}$ and $F_{v}$

- NEU00/NEU51 Observed Amplification

$\triangle \quad$ NEU00/JP Observed Amplification

Figure 11: Mean amplification and fundamental period versus depth to bedrock (for various linear and equivalent-linear models, including the $\mathrm{F}_{\mathrm{a}}$ and $\mathrm{F}_{\mathrm{v}}$ lines): (a) mean short-period amplification, (b) mean intermediate-period amplification, and (c) fundamental period. The lines for the site coefficients have been selected based on the design ground motion levels for Boston (selected for site class A), as well as the average shear-wave velocities of the profiles. The profiles with $\mathrm{H} \leq 15 \mathrm{~m}$ are site class $\mathrm{C}$, and the profiles with $\mathrm{H}>15 \mathrm{~m}$ are site class $\mathrm{D}$ (hence the discontinuity at $\mathrm{H}=15$ ). Also shown are the observed mean amplifications for the Northeastern University surface/downhole pair (NEU00/NEU51) and surface/outcrop pair (NEU00/JP), discussed in section 3.3. 
(a) $\mathrm{H}=10 \mathrm{~m}$

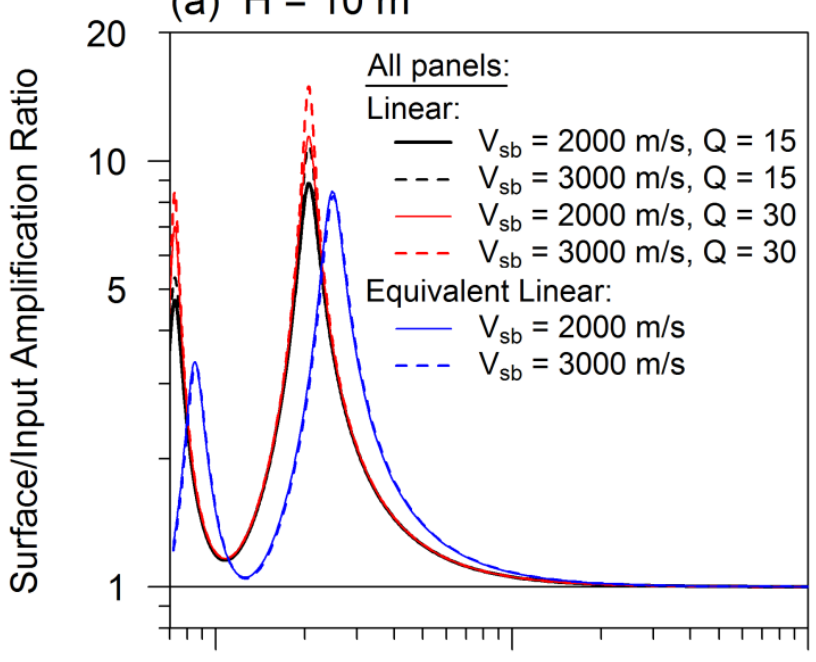

(c) $\mathrm{H}=50 \mathrm{~m}$

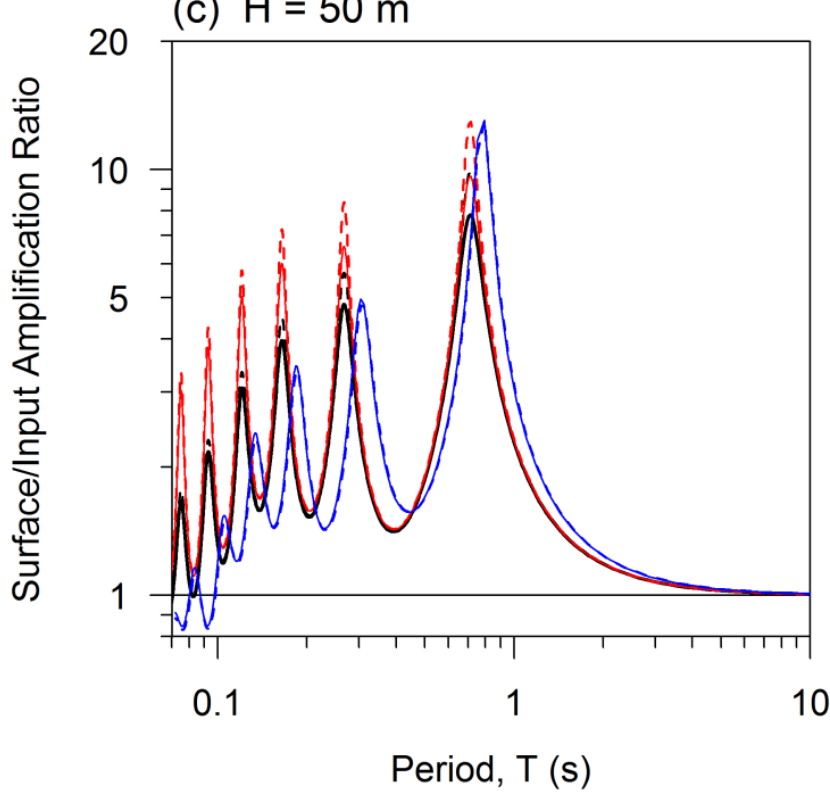

(b) $\mathrm{H}=30 \mathrm{~m}$

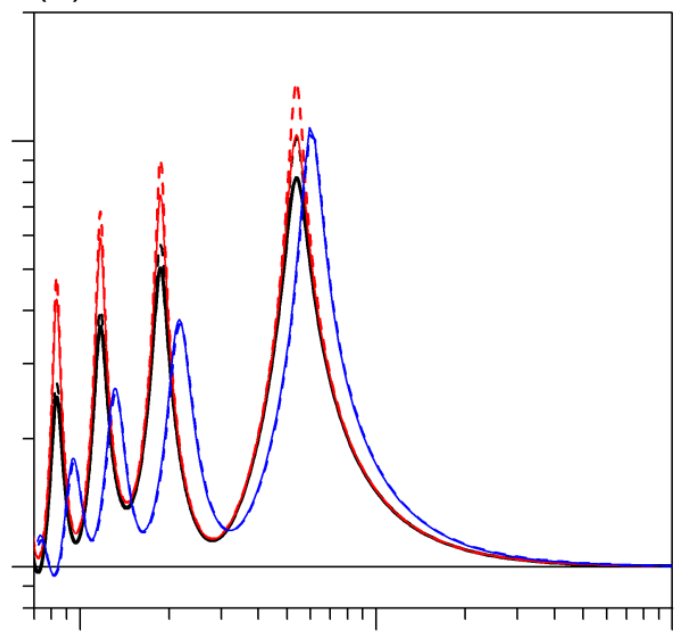

(d) $\mathrm{H}=80 \mathrm{~m}$

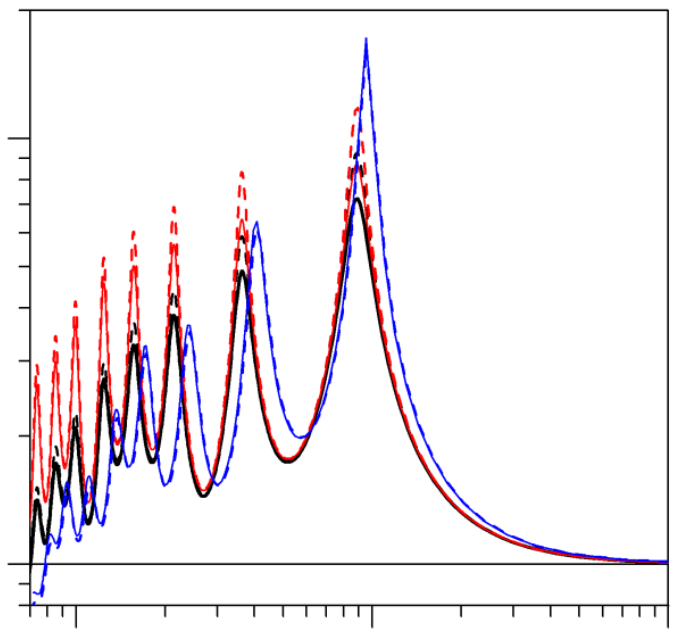

0.1

Figure 12. Site response transfer functions for various linear and equivalent-linear models for the generic $\mathrm{V}_{\mathrm{S}}$ profile truncated at different bedrock depths: (a) $\mathrm{H}=10 \mathrm{~m}$, (b) $\mathrm{H}=30 \mathrm{~m}$, (c) $\mathrm{H}=$ $50 \mathrm{~m}$, and (d) $\mathrm{H}=80 \mathrm{~m}$. 
(a)

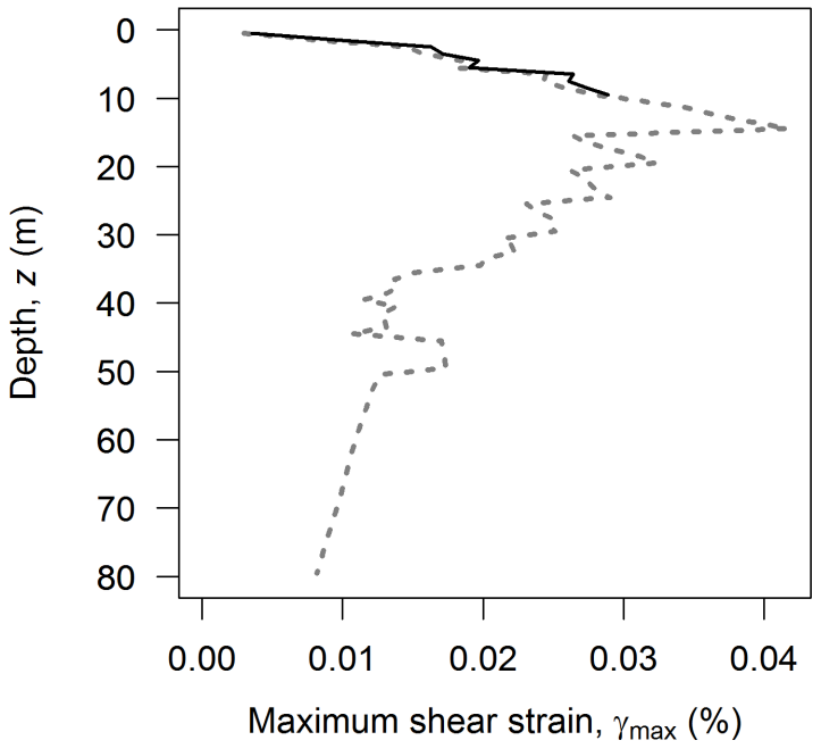

(c)

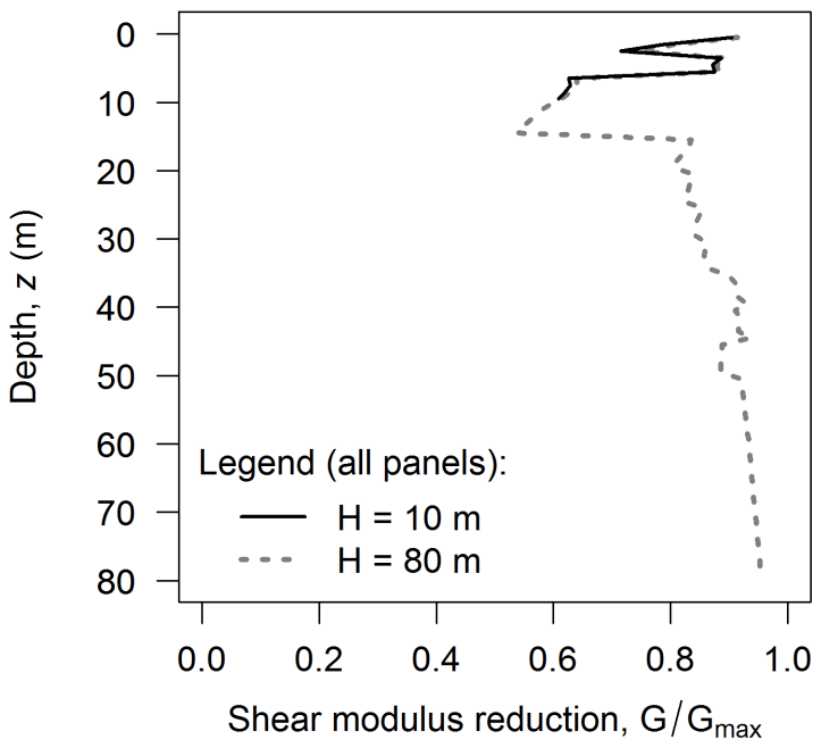

(b)

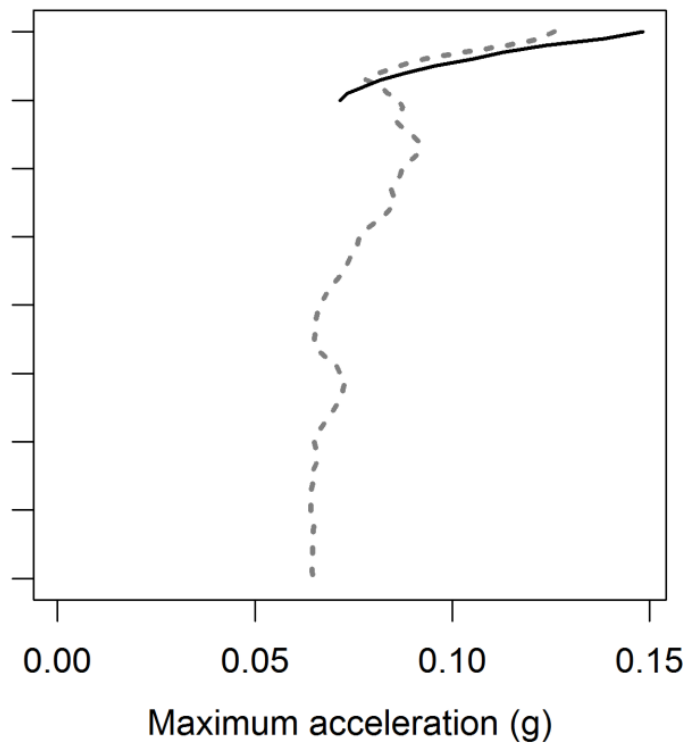

(d)

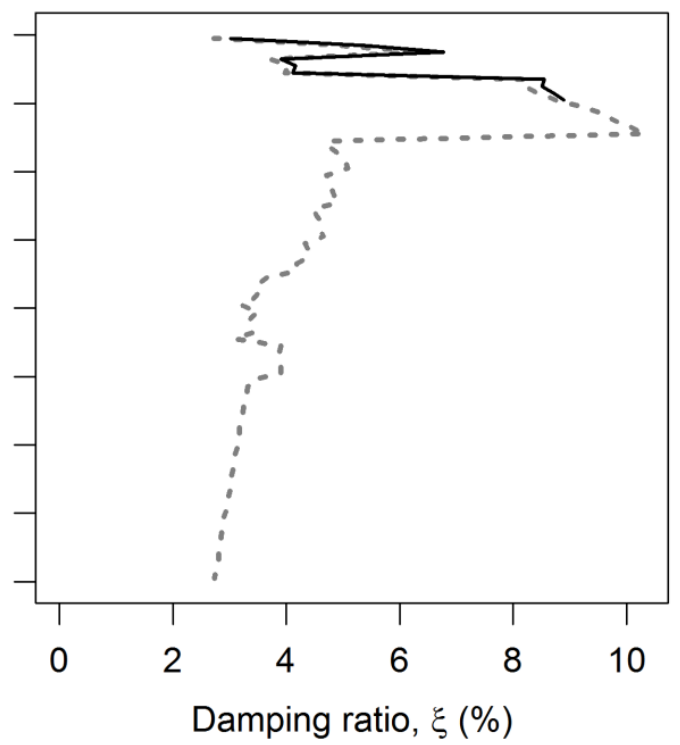

677

678 Figure 13. Plots of equivalent-linear profiles versus depth for soil column heights of $\mathrm{H}=10 \mathrm{~m}$ 679 and $\mathrm{H}=80 \mathrm{~m}$ : (a) maximum shear strain, (b) maximum acceleration, (c) shear modulus 680 reduction, and (d) damping ratio. 
Figure 14: Fourier amplitude spectra of the surface (NEU00), downhole bedrock (NEU51), and outcrop (Jamaica Pond, JP) ground motions for the 2011 M 5.8 Mineral Virginia, earthquake recorded in Boston.

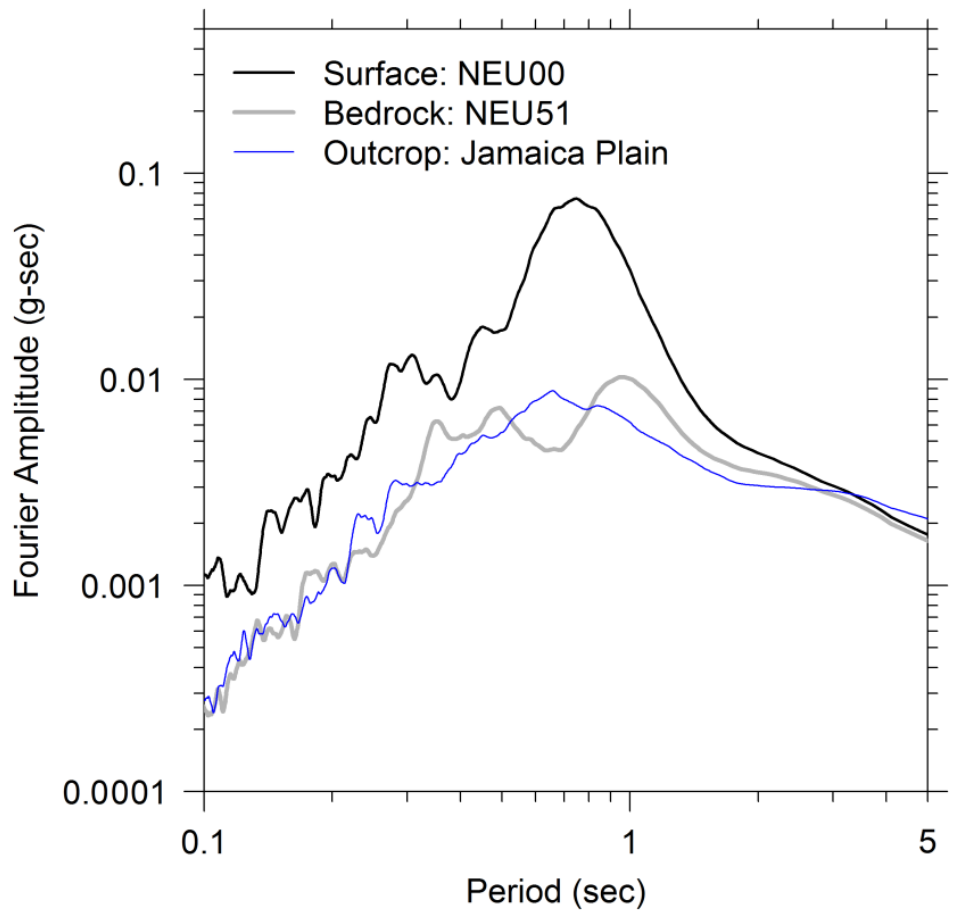




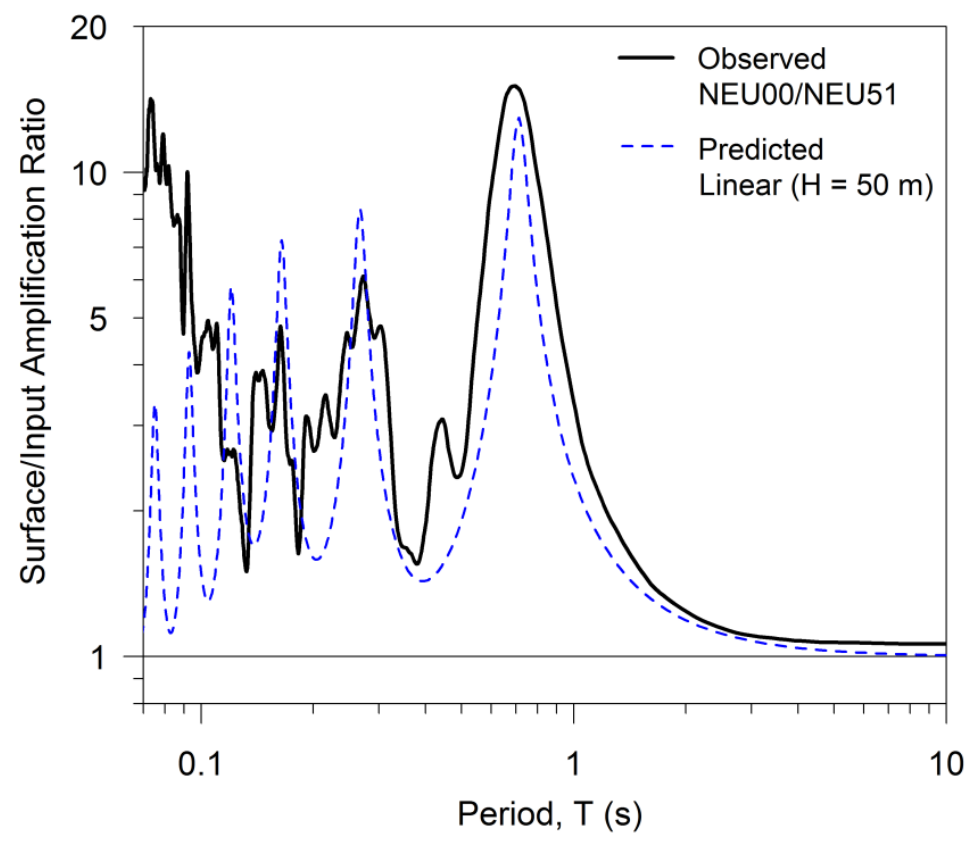

692 Figure 15: Observed and predicted transfer functions for the Mineral, Virginia, earthquake at the 693 NEU vertical seismometer array. The predictions are plotted for the generic $\mathrm{V}_{\mathrm{S}}$ profile in 694 artificial fill using the linear site response model with $\mathrm{V}_{\mathrm{Sb}}=3000 \mathrm{~m} / \mathrm{s}$ and $\mathrm{Q}=30$ fo the observed 695 bedrock depth of $50 \mathrm{~m}$. 